Portland State University

PDXScholar

TREC Final Reports

Transportation Research and Education Center

(TREC)

$12-2015$

\title{
Investigations In Transportation
}

William G. Becker

Portland State University

Carol Biskupic Knight

Portland State University

Follow this and additional works at: https://pdxscholar.library.pdx.edu/trec_reports

Part of the Transportation Commons, Urban Studies Commons, and the Urban Studies and Planning Commons

Let us know how access to this document benefits you.

Recommended Citation

Becker, William and Carol Biskupic Knight. Investigations In Transportation. NITC-ED-680. Portland, OR: Transportation Research and Education Center (TREC), 2015. https://doi.org/10.15760/trec.82

This Report is brought to you for free and open access. It has been accepted for inclusion in TREC Final Reports by an authorized administrator of PDXScholar. Please contact us if we can make this document more accessible: pdxscholar@pdx.edu. 


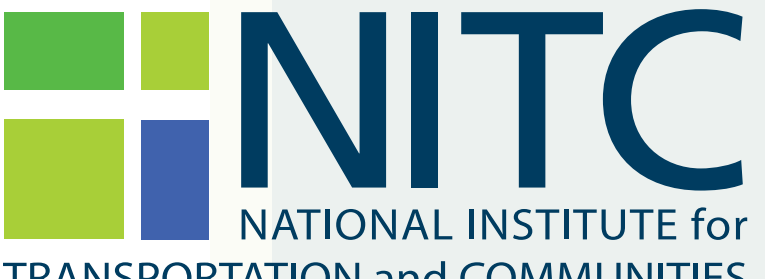

TRANSPORTATION and COMMUNITIES

FINAL REPORT

Investigations In Transportation

NITC-ED-680 December 2015

NITC is the U.S. Department of Transportation's national university transportation center for livable communities.

H:" TREC 


\title{
INVESTIGATIONS IN TRANSPORTATION
}

\author{
Final Report
}

NITC-ED-680

By

Principal Investigator: Dr. William Becker

Co-Investigator: Carol Biskupic Knight

Portland State University

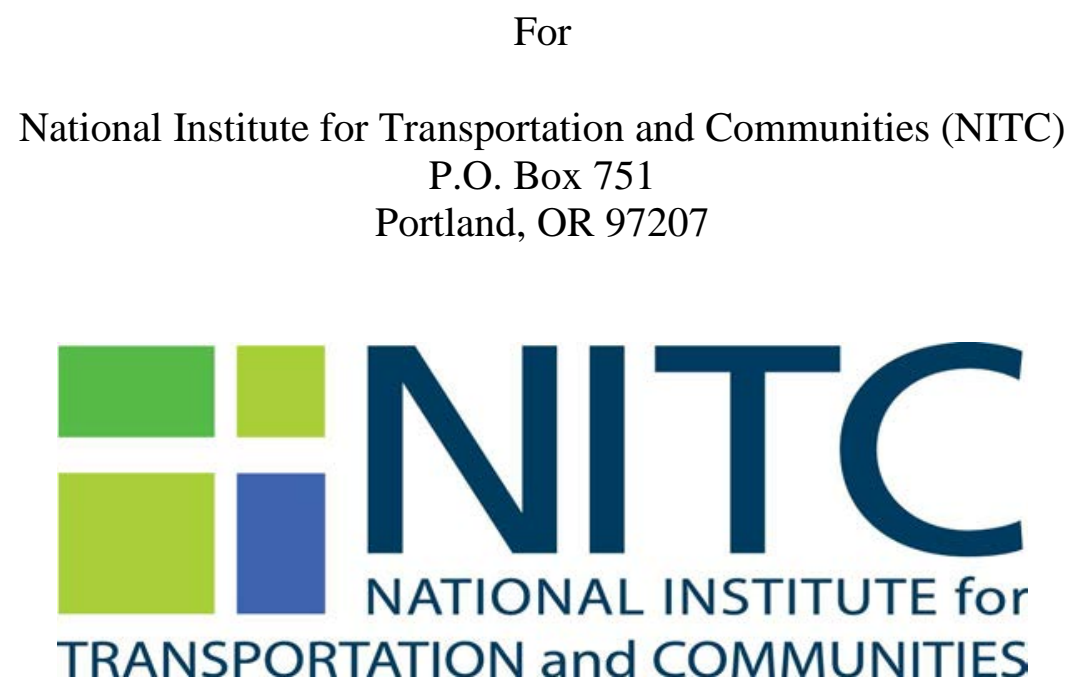

December 2015 


\section{Technical Report Documentation Page}

\begin{tabular}{|c|c|c|}
\hline $\begin{array}{l}\text { 1. Report No. } \\
\text { NITC-ED-680 }\end{array}$ & 2. Government Accession No. & 3. Recipient’s Catalog No. \\
\hline \multicolumn{2}{|l|}{ 4. Title and Subtitle } & $\begin{array}{c}\text { 5. Report Date } \\
12-1-2015\end{array}$ \\
\hline \multicolumn{3}{|c|}{ Investigations in Transportation } \\
\hline & & 6. Performing Organization Code \\
\hline \multicolumn{2}{|c|}{$\begin{array}{l}\text { 7. Author(s) } \\
\text { Carol Biskupic Knight }\end{array}$} & 8. Performing Organization Report No. \\
\hline \multicolumn{2}{|c|}{ 9. Performing Organization Name and Address } & 10. Work Unit No. (TRAIS) \\
\hline \multicolumn{2}{|c|}{ Portland State University Center for Science Education } & 11. Contract or Grant No. \\
\hline \multicolumn{2}{|c|}{ 12. Sponsoring Agency Name and Address } & 13. Type of Report and Period Covered \\
\hline \multicolumn{2}{|c|}{$\begin{array}{l}\text { National Institute for Transportation and Communities (NITC) } \\
\text { P.O. Box } 751 \\
\text { Portland, Oregon } 97207\end{array}$} & 14. Sponsoring Agency Code \\
\hline
\end{tabular}

15. Supplementary Notes

16. Abstract

This report presents a study of a transportation education partnership and curriculum development project that harnessed the professional expertise, experience and enthusiasm of transportation-sector STEM workers by creating a mechanism and set of protocols by which they engaged with elementary school teachers to develop and implement an instructional unit. This STEM-connected instructional unit and lessons allowed students to explore and investigate issues central to transportation. The unit incorporated and enhanced the content and practice standards outlined by the Common Core State Standards and Next Generation Science Standards, and relied heavily on the instructional and curriculum expertise and experience of classroom teachers to develop an age- and interest-appropriate unit of study. This collaboration resulted in the development of an Investigations in Transportation instructional unit that provided students with rich, engaging learning opportunities set in the context of real-world problems around a school parking lot dilemma focused on safety, sustainability and health concerns.

The education project team utilized a coherent and cohesive curriculum development process for unit creation and evaluated the development, implementation and reflection of the unit through teacher and student surveys/assessments of attitudes, identity and conceptual understanding. The report describes the process successes, challenges and replication opportunities.

\section{Key Words}

18. Distribution Statement

No restrictions. Copies available from NITC:

Transportation, unit development, Common Core, NGSS, STEM www.nitc.us

\begin{tabular}{|l|l}
\hline $\begin{array}{l}\text { 19. Security Classification (of this report) } \\
\text { Unclassified }\end{array}$ & $\begin{array}{c}\text { 20. Security Classification (of this page) } \\
\text { Unclassified }\end{array}$ \\
\hline
\end{tabular}




\section{ACKNOWLEDGEMENTS}

This project was funded by the National Institute for Transportation and Communities (NITC) through a sub-grant from the Transportation Research Education Consortium (TREC). Special appreciation goes out to Beaverton School District; Hillsboro School District; Oregon Department of Transportation; Kittelson \& Associates; DKS Associates; Murray, Smith \& Associates; and the Portland Metro STEM Partnership.

\section{DISCLAIMER}

The contents of this report reflect the views of the authors, who are solely responsible for the facts and the accuracy of the material and information presented herein. This document is disseminated under the sponsorship of the U.S. Department of Transportation University Transportation Centers Program in the interest of information exchange. The U.S. Government assumes no liability for the contents or use thereof. The contents do not necessarily reflect the official views of the U.S. Government. This report does not constitute a standard, specification, or regulation. 


\section{TABLE OF CONTENTS}

EXECUTIVE SUMMARY. 1

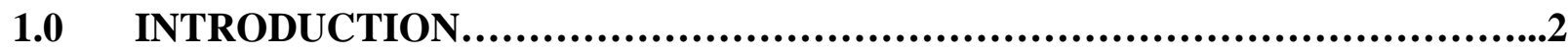

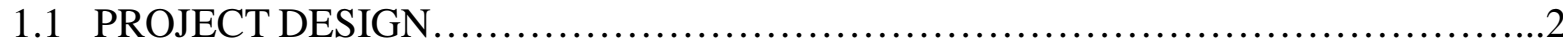

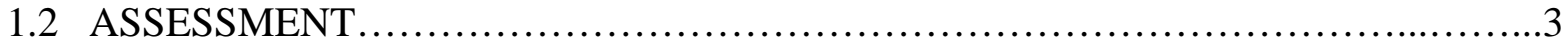

2.0 BACKGROUND AND OBJECTIVES...............................................4

2.1 LITERATURE REVIEW ..........................................................

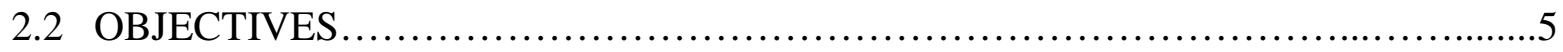

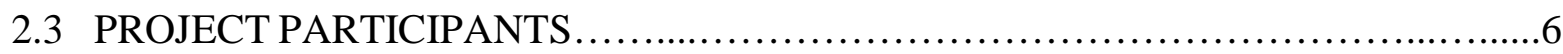

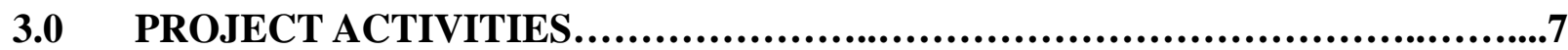

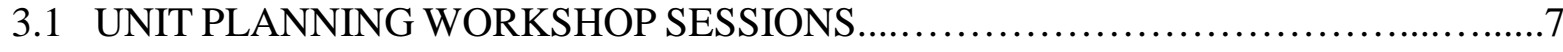

3.1.1 Steps Taken as Part of Collaborative Unit Planning.................................

3.2 UNIT IMPLEMENTATION..................................................

3.2.1 Steps Taken as Part of Bringing Colleagues and Students on Board..................12

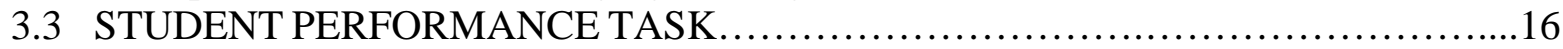

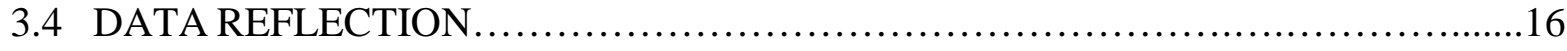

3.4.1 Teacher Instructional Practices Reflection.............................................16

3.4.2 Cross Schools Collaborative Data Reflection Session................................17

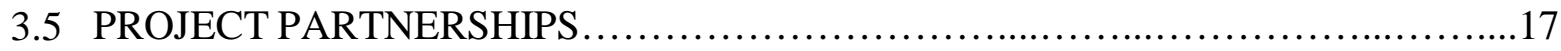

3.5.1 Project Support and Staff Personnel..................................................17

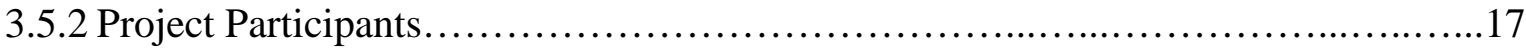

3.5.3 Transportation Professionals..........................................................

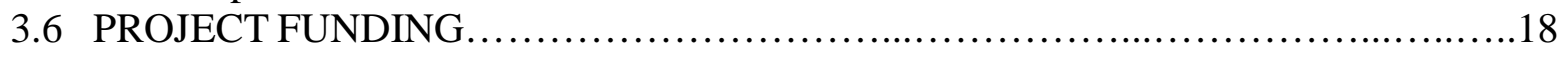

\subsection{EVALUATION AND PROJECT OUTCOMES......................................19}

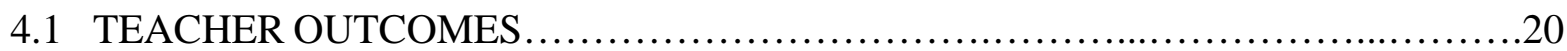

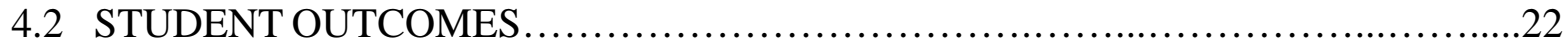

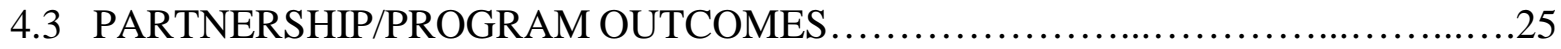

4.4 PROJECT STRENGTHS, CHALLENGES AND LESSONS LEARNED ..............26

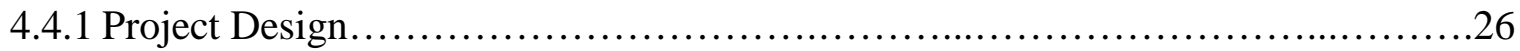

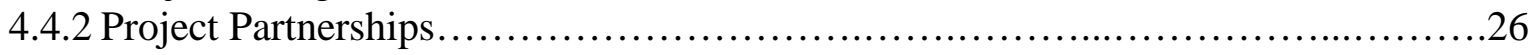

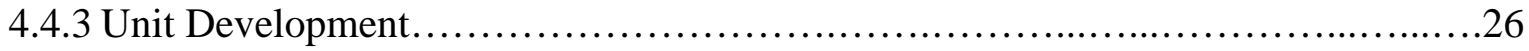

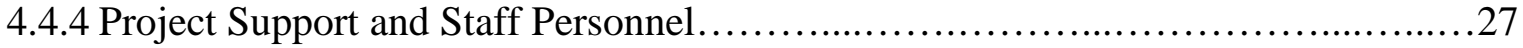

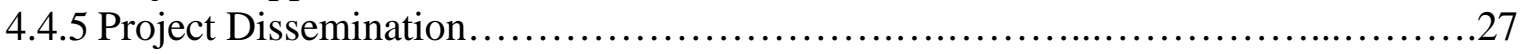

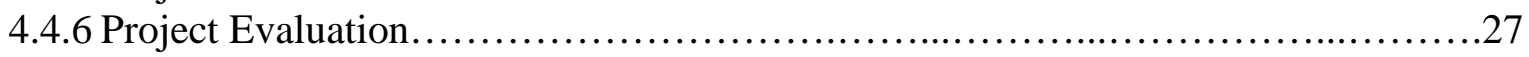


5.1 NATIONAL SCIENCE TEACHER ASSOCIATION CONFERENCE....................28

5.2 BEAVERTON SCHOOL BOARD RECOGNITION .................................28

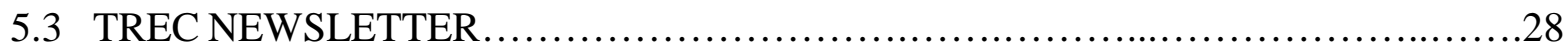

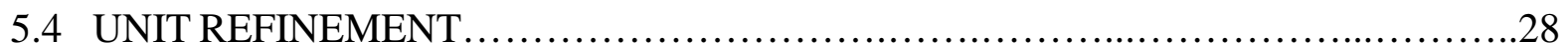

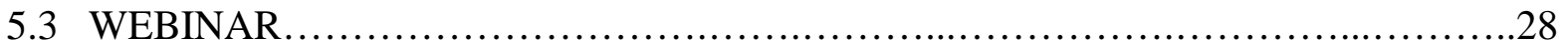

\subsection{APPENDICES}

APPENDIX A: NATIONAL SCIENCE TEACHER ASSOCIATION PROPOSAL............A-1

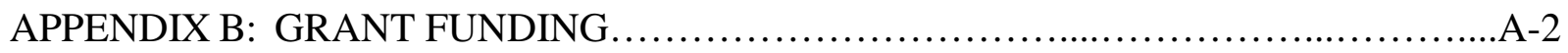

APPENDIX C: UNIT MATERIALS PURCHASED .....................................

\section{LIST OF TABLES}

Table 2.1: Project participants .6

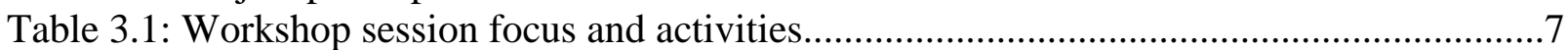

Table 3.2: Unit sharing and implementation.........................................................................11

Table 4.1: Teacher Instructional Practices (TIP) process artifacts................................................20

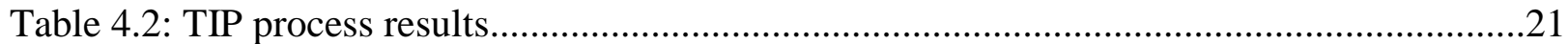

Table 4.3: Aggregate results for Tobias Elementary School....................................................23

Table 4.3: Aggregate results for Chehalem Elementary School.................................................24

\section{LIST OF FIGURES}

Figure 1.1: Tobias students share Parking Lot Dilemma solution plan.........................................

Figure 3.1: Portland Metro STEM Partnership theory of change..................................................

Figure 3.2: Chehalem students measure parking lot using grant purchased equipment..............12

Figure 3.3: Tobias students use math skills to measure identify car dimensions..........................13

Figure 3.4: Transportation professionals share career connections to parking lot dilemma..........14

Figure 3.5: Chehalem students analyze and apply data to parking lot solutions.....................14

Figure 3.6: Tobias students present to stakeholders.............................................................15

Figure 3.7: Performance task to assess application of conceptual knowledge................................16 


\section{EXECUTIVE SUMMARY}

The Portland metropolitan region is home to a high concentration of businesses from the manufacturing, construction, high tech, and computer science sectors, all of which rely on a highly skilled STEM workforce. Many current STEM workers are also anxious to engage in the education system, but it is not always clear how they may best impact students and schools. Classroom teachers, especially at the elementary level, often lack the understanding of the reallife applicability of the knowledge and skills necessary for workers in STEM careers. Time for partnership-based, integrated unit development by classroom teachers is also limited. This report presents a study of a transportation education partnership and curriculum development project that harnessed the professional expertise, experience and enthusiasm of transportation-sector STEM workers by creating a mechanism and set of protocols by which they engaged with elementary schoolteachers to develop and implement an instructional unit. This STEMconnected instructional unit and lessons allowed students to explore and investigate issues central to transportation. The unit incorporated and enhanced the content and practice standards outlined by the Common Core State Standards and Next Generation Science Standards, and relied heavily on the instructional and curriculum expertise and experience of classroom teachers to develop an age- and interest-appropriate unit of study. This collaboration resulted in the development of an Investigations in Transportation instructional unit that provided students with rich, engaging learning opportunities set in the context of real-world problems around a school parking lot dilemma focused on safety, sustainability and health embedded in STEM.

The education project team utilized a coherent and cohesive curriculum development process for unit creation, and evaluated the development, implementation and reflection of the unit through teacher and student assessments of attitudes, academic identity and conceptual understanding. The report describes the process successes, challenges and replication opportunities. Focusing on a partnership with the Oregon Department of Education and transportation consulting agencies, the project report identifies the work by lead teachers working with transportation professionals to create the unit, the steps taken to bring colleagues and students on board during the implementation process, and then final reflection of the unit by the teacher team with the grant researcher and staff. 


\subsection{INTRODUCTION}

\subsection{PROJECT DESIGN}

The Investigations in Transportation project consisted of four phases over an 18-month period beginning January 2014 and ending in June 2015.

Phase 1: Development and Design (January 2014-March 2014). The Portland Metro STEM Partnership (PMSP) recruited STEM professionals from the Oregon Department of Transportation (ODOT) and Portland-area transportation agencies as part of a match of in-kind volunteer hours for the project. A detailed timeline for initial project development incorporating best practices for mentoring and instruction was developed by the following grant staff: Project Coordinator, Carol Biskupic Knight; Grant Researcher, Emily Saxton; and the project Partnership Liaison, Melissa Dubois. PMSP worked with partnering school districts to recruit schools and teachers. The fifth-grade team of teachers (three at each school) from Beaverton School District's Chehalem Elementary and Hillsboro School District's Tobias Elementary were identified as the partnering schools and teacher teams. Wendy Gould (Chehalem) and Jennifer LeCorre (Tobias) were identified as lead teachers. Tova Peltz from ODOT recruited six transportation engineers from both ODOT and private-sector engineering firms Kittelson \& Associates, DKS Associates and Murray, Smith \& Associates.

Phase 2: Project Development (April-August 2014). A series of six 3-hour planning sessions with transportation professionals from ODOT and the consulting firms, lead teachers from Tobias and Chehalem schools, and PSU programming and research staff were held to design and develop a curriculum unit which became the core of the Investigations in Transportation project. These sessions focused on capacity building around the standards (Common Core State Standards and the Next Generation State Standards) along with effective instructional practices. Transportation professionals provided a perspective and lens of the knowledge and skills they use in their jobs, and made connections to the potential instructional links for engaging students in a transportation engineering design experience to solve a real-life dilemma: the school parking lot. An initial unit outline of experiences was co-developed in the planning sessions. Lead teachers, project staff and school-based STEM curriculum leaders continued to meet to create a 21-session plan for implementation with students.

Phase 3: Project Implementation (September 2014-February 2015). Lead teachers shared units with colleagues. Each school modified and elaborated the initial plan to fit its own instructional needs and barriers. Chehalem did full-day integration of the lessons over a threeweek period, focusing on the engineering component of the unit with the math and science content to support the engineering process. Tobias blended several content areas over a six-week period, focusing on the math skills needed to bring the engineering and science to fruition. Two of the initial transportation professionals volunteered at both schools during the unit 
implementation with students. Teachers collected formative assessment data on student outcomes, and reflected on their teaching practices during ongoing team meetings throughout the unit.

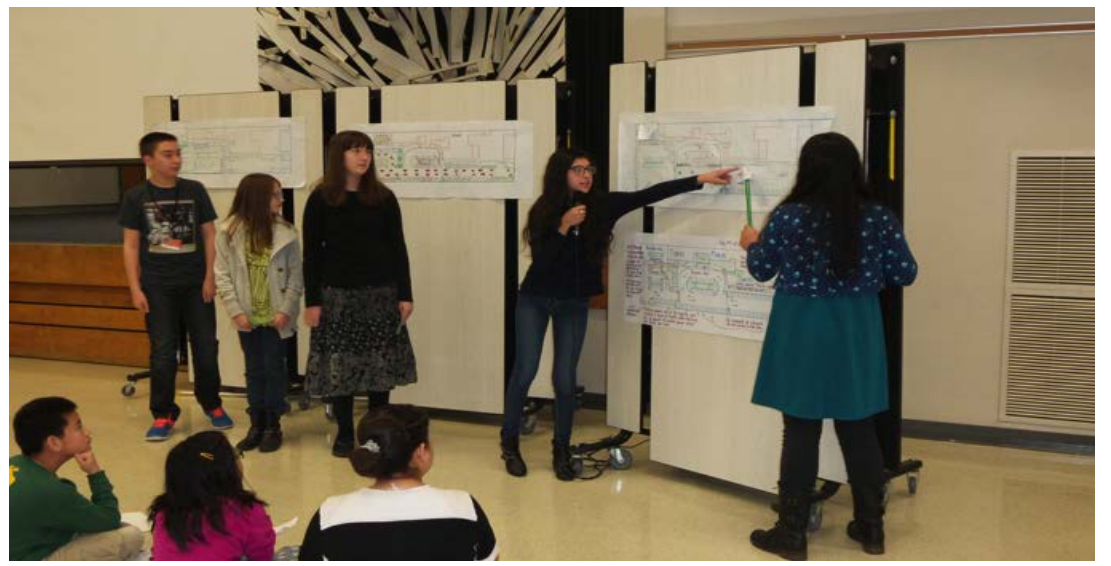

Figure 1.1: Tobias students share Parking Lot Dilemma solution plan.

Phase 4, Part 1: Assessment and Dissemination (March-June 2015). The PMSP Office of Research and Assessment compiled the formative and summative assessment data from the Investigations in Transportation project implementation provided by both students and teachers. A data reflection session was held on February 26, 2015. Lead and collaborating teachers reflected on the unit implementation and the impact on student learning and STEM identity. The data from this session is described in the evaluation section of this report as part of determining the efficacy of the program and the documentation of its impact. Initial dissemination of the project, both the curriculum unit and the project design, occurred at the National Science Teachers Association Conference session held in Chicago on March 12, 2015. Lead teachers Jennifer LeCorre and Wendy Gould and project coordinator Carol Biskupic Knight presented at the conference. The project was also recognized by the partnering school districts.

Phase 4, Part 2: Further Dissemination (September 2015-April 2016). A no-cost extension was requested and received in order to do further refinement of the unit format to make it more accessible for classroom teachers to replicate the project. This updated unit will be disseminated to regional and statewide school districts and transportation agencies through listservs, networks and websites, including the Oregon Education Network and Oregon Science Teacher Association. Additionally, a webinar for both classroom teachers and transportation professionals will be developed for spring 2016 to assist in the replication of the partnership process between transportation professionals and educators that was the keystone of the Investigations in Transportation project.

\subsection{ASSESSMENT}

The impact of this program was assessed using measures developed by the PMSP's Office of Research and Assessment. Formative and summative instruments were used to determine the impact of the programming. The specific outcomes addressed include the academic identity and motivational resilience of students; students' ability to apply conceptual STEM knowledge; and teachers' reflections on changes in instructional practices, student successes and challenges. 


\subsection{BACKGROUND \& OBJECTIVES}

\subsection{LITERATURE REVIEW}

The proposal engaged partners from the transportation sector to work with teachers and students to enhance student understanding of transportation issues. A review of the transportation literature (2010-2013, TRID database) related to elementary schools and elementary education yielded several reports that assessed student or community behavior and policy related to vehicular and Active School Transportation (Price, Pluto, Ogoussan \& Banda, 2011; Wilson, Marshall, Wilson \& Krizel, 2010); assessed health implications of transportation-related policies and behaviors (Hu et al., 2011; Trapp et al., 2011); or educated students about transportation-related issues (Hammond, Cherrett \& Waterson, 2013). One ongoing project at Colorado State University sought to create a community partnership to teach teachers about transportation so they might in turn educate students on issues of transportation infrastructure and make students aware of transportation-related career choices (Educational and Workforce Development Proposal: STEM Outreach at Colorado State University, 2012-2016). The Department of Defense reported a successful elementary education program in which professionals from the Military Surface Deployment and Distribution Command's Transportation Engineering Agency made presentations and engaged in hands-on projects with elementary school students in Illinois to demonstrate the STEM skills and practices needed to move Humvees around the world for the U.S. military (Peterson, 2010). However, all of these projects differed from the paradigm of this project. None of these projects created partnerships between classroom educators and industry professionals to develop project-based education materials to draw from the experience and expertise of all stakeholders. They also failed to take advantage of the valuable opportunity to engage students in constructing their own STEM knowledge through the real-world context of transportation investigations. For example, reports described assessing student use of transportation modes (Trapp et al., 2011; Wilson et al., 2010), but none seized the opportunity to engage students in these assessments or to allow students to take ownership of their new knowledge and support the dissemination of new information in their community. The Investigations in Transportation project built on the content knowledge of classroom teachers through their experiences with industry professionals; provided STEM professionals with an opportunity to directly impact students and teachers by sharing their specialized knowledge of transportation issues; and allowed students to dive into real-world problems using tools and practices that STEM professionals use to solve problems, resulting in a unit of study that will be disseminated to other schools and districts.

STEM education in Oregon is on the threshold of change. Static scores in student science and mathematics assessments and a critical shortage of STEM-capable workers have resulted in a mandate to improve student achievement in STEM. This call to action is being answered with the state's adoption of the Common Core State Standards (CCSS) in English Language Arts and Mathematics (http://www.corestandards.org/Math) and the Next Generation Science Standards 
(NGSS, http://www.nextgenscience.org/next-generation-science-standards), and through strategic investments. The CCSS-M and the NGSS are curricular documents that establish gradelevel STEM learning outcomes for all K-12 students. Together, these standards raise the bar to engage students in deeper learning of the cognitive skills (e.g., problem solving, development of arguments based on evidence, communicating ideas) and conceptual knowledge (i.e., application of content knowledge to a broad array of contexts and academic disciplines) necessary for college and career readiness, and are a hand-in-glove fit with the Common Outcomes framework of the PMSP.

Oregon ranked last among all states in 2009 with respect to the numbers of hours of science instruction that elementary students receive (U.S. Dept. of Education, 2009). Further, many elementary teachers lack deep content knowledge in STEM disciplines, owing to the lack of requirements in most states for teachers at these grade levels to complete STEM coursework as a condition of their teacher preparation and certification. By creating new interfaces with local STEM professionals in this project, teachers built STEM content knowledge while engaging students in transportation projects that were meaningful, relevant, and connected to their lives outside of school.

\subsection{OBJECTIVES}

The project identified the following deliverables:

1) Development of one unit of study related to safe and sustainable transportation that meets Common Core State Standards (Math), Next Generation Science Standards and targeted outcomes of the PMSP Common Outcomes framework.

2) Identification and codification of protocols for collaboration between classroom teachers and STEM professionals for development and implementation of classroom activities.

The impact of this program was assessed using measures associated with the PMSP Common

Outcomes framework, a research-based set of outcomes that are critical to the development of college and career readiness attributes for students in STEM. This framework includes outcomes associated with students and teachers, as well as professional development. The following are the student and teacher outcomes of the project:

\section{Student Outcomes:}

A. Motivational Resilience. Students will demonstrate high-quality participation in academic work, including hard work, resilience, enthusiasm and curiosity. Definition: Characterized by students' enthusiastic hard work and persistence in the face of challenging STEM coursework; includes components of academic engagement and constructive coping/persistence. Rationale: Whole-hearted engagement and tenacity in demanding STEM classwork is essential to student learning and achievement (Furrer \& Skinner, 2003; Skinner, Kindermann \& Furrer, 2009).

B. Application of Conceptual Knowledge. Students know how to apply math conceptual knowledge to solve problems, including scientific inquiry and engineering design. 
Definition: Students' understanding of and thinking about ideas, theories and perspectives considered critical or essential within an academic or professional discipline, or in STEM interdisciplinary fields recognized in authoritative scholarship. Rationale: The focus on deep understanding and application of conceptual knowledge is key to student success in STEM because it more accurately reflects how scientists, engineers and other STEM professionals apply these concepts in the real-world context. This outcome stands in stark contrast to rote memorization of isolated facts, definitions, formulas or algorithms because application of conceptual knowledge results in a longer-lasting understanding of STEM content.

\section{Educator Outcomes:}

A. Effective Instructional Practices.

a. Teachers will emphasize deep content knowledge and higher-order cognitive skills by addressing learning goals in these areas (Miner et al., 2010).

b. Teachers will create and implement multiple and diverse opportunities for students to develop conceptual knowledge and cognitive skills (Stein, Smith, Henningsen \& Silver, 2009).

\section{B. Pedagogical Content Knowledge.}

a. Teachers' understanding and use of the effective strategies for specific STEM topics, including strategies to engage students in inquiry, represent STEM phenomena and guide discourse about the STEM topic (Shulman, 1986).

\subsection{PROJECT PARTICIPANTS}

Table 2.1: Project Participants

\begin{tabular}{l|l|l}
\hline Participants & Number & Role in Grant \\
\hline Lead Teachers & 2 & $\begin{array}{l}\text { Plan, share, implement and reflect on } \\
\text { transportation unit }\end{array}$ \\
\hline Collaborating Teachers & 4 & $\begin{array}{l}\text { Revise and implement transportation unit } \\
\text { Assess students and reflect on implementation }\end{array}$ \\
\hline Transportation Professionals & 7 & $\begin{array}{l}\text { Support unit planning } \\
\text { Work with students during unit implementation }\end{array}$ \\
\hline Portland State University Staff & 2 & $\begin{array}{l}\text { Design and coordinate programming } \\
\text { Monitor implementation }\end{array}$ \\
\hline Transportation Partnering Agencies or & 2 & $\begin{array}{l}\text { Recruit and release grant transportation } \\
\text { volunteers }\end{array}$ \\
\hline Transportation Consultant Firms & 4 & $\begin{array}{l}\text { Engage in unit activities } \\
\text { Demonstrate math and science understanding }\end{array}$ \\
\hline Students & $160+$ &
\end{tabular}




\subsection{PROJECT ACTIVITIES}

\subsection{UNIT PLANNING WORKSHOP SESSIONS}

April 2014-September 2014: Each three-hour session had a specific focus as part of coherent unit planning and development. The grant coordinator designed each of the workshop sessions aligned to grant objectives and outcomes. Based on monitoring of the participants during the session and feedback elicited at the end of each session, the grant coordinator adjusted the next steps and activities to meet participating teachers' and transportation professionals' needs.

Table 3.1: Workshop Session Focus and Activities

\begin{tabular}{|c|c|c|c|}
\hline Session & Workshop Focus & Participants & Activities \\
\hline $\begin{array}{l}1 \\
\text { April 7, } \\
2014\end{array}$ & $\begin{array}{l}\text { Develop understanding of } \\
\text { participants' background and create } \\
\text { connections. } \\
\text { Connect the various aspects of } \\
\text { standards work and the Investigations } \\
\text { in Transportation grant to present } \\
\text { understanding of science and math } \\
\text { instruction. } \\
\text { Use the knowledge and expertise of } \\
\text { the group for future unit planning. }\end{array}$ & $\begin{array}{l}\text { Coordinator } \\
\text { Grant Researcher } \\
\text { Partnership } \\
\text { Director } \\
\text { Lead Teachers (2) } \\
\text { Transportation } \\
\text { Engineers (5) } \\
\text { ODOT Project } \\
\text { Manager }\end{array}$ & $\begin{array}{l}\text { Welcome, Introductions and } \\
\text { Connections: License Plate } \\
\text { Activity } \\
\text {. } \quad \text { Partnership Theory of Change } \\
\text { and Intro to Standards } \\
\text {. Science-Math Integration } \\
\text { Investigation in Action: Magic } \\
\text { Sand Activity } \\
\text { A Closer Look at the Standards } \\
\text { and Next Steps }\end{array}$ \\
\hline $\begin{array}{l}2 \\
\text { April } \\
21,2014\end{array}$ & $\begin{array}{l}\text { Connect the standards work and the } \\
\text { Investigations in Transportation grant } \\
\text { work to present understanding of } \\
\text { science and math instruction and } \\
\text { identify integration points. } \\
\text { - Use the knowledge and expertise of } \\
\text { the group to begin unit planning. } \\
\text {. Identify approaches to content }\end{array}$ & $\begin{array}{l}\text { Coordinator } \\
\text { Grant Researcher } \\
\text { Lead Teachers (2) } \\
\text { Transportation } \\
\text { Engineers (6) } \\
\text { ODOT Project } \\
\text { Manager }\end{array}$ & $\begin{array}{ll}\text { - } & \text { Building a Level of Trust } \\
\text { - } & \text { Standards Connections } \\
\text { · } & \text { Industry Professionals: Science, } \\
\text { Technology, Engineering and } \\
\text { Math, Knowledge and Skills in } \\
\text { Their Work } \\
\text { Exemplars and Brainstorming: } \\
\text { Initial Decisions }\end{array}$ \\
\hline $\begin{array}{l}3 \\
\text { May 5, } \\
2014\end{array}$ & $\begin{array}{l}\text { Finalize unit topic and culminating } \\
\text { project. } \\
\text { Identify integration points for } \\
\text { transportation learning experiences } \\
\text { and mentor/industry professional } \\
\text { involvement. } \\
\text { - Use the knowledge and expertise of } \\
\text { the group for unit planning. }\end{array}$ & $\begin{array}{l}\text { Coordinator } \\
\text { Grant Researcher } \\
\text { Lead Teachers (2) } \\
\text { Transportation } \\
\text { Engineers (5) }\end{array}$ & $\begin{array}{ll}\cdot & \text { Transportation Connections } \\
\text {. } & \text { Continued Brainstorming-Unit } \\
& \text { Format and Final Topics and } \\
& \text { Culminating Investigation } \\
\text {. } & \text { Sequence of Transportation } \\
& \text { Experiences } \\
\text {. } & \text { Elements of an Effective Unit }\end{array}$ \\
\hline $\begin{array}{l}4 \text { and } 5 \\
\text { May } 18 \\
\text { and June } \\
2,2014 \\
\end{array}$ & $\begin{array}{ll}\text { · } & \text { Develop unit lessons and activities } \\
\text { framework } \\
\text { · } & \text { Identify preliminary lesson specifics }\end{array}$ & $\begin{array}{l}\text { Coordinator } \\
\text { Grant Researcher } \\
\text { Lead Teachers (2) } \\
\text { Professionals (2) } \\
\end{array}$ & $\begin{array}{ll} & \text { Unit Planning } \\
\cdot & \text { Lesson Design }\end{array}$ \\
\hline $\begin{array}{l}6 \text { and } \\
\text { Added } \\
\text { Sessions } \\
\text { Sept. } 8 \text {, } \\
\text { Sept. } 15 \text {, } \\
2014\end{array}$ & $\begin{array}{l}\text { Review unit topic and culminating } \\
\text { project and initial day-to-day planning } \\
\text { - Use the knowledge and expertise of } \\
\text { the group for standards and } \\
\text { transportation context alignment and } \\
\text { planning. }\end{array}$ & $\begin{array}{l}\text { Coordinator } \\
\text { Grant Researcher } \\
\text { Lead Teachers (2) } \\
\text { School STEM } \\
\text { Leaders (2) }\end{array}$ & $\begin{array}{ll}\text {. } & \text { Alignment and Day-to-Day } \\
& \text { Sequencing } \\
\cdot & \text { Assessment Opportunities } \\
\cdot & \text { Determination of Transportation } \\
& \text { Professional Involvement and } \\
& \text { Completion of Initial Plans }\end{array}$ \\
\hline
\end{tabular}




\subsubsection{Steps Taken as Part of Collaborative Unit Planning}

\section{Build relationships and trust.}

One of the key aspects of this project was to bring together classroom teachers and transportation professionals, along with curriculum specialists and researchers, to collaboratively create a unit. By doing teambuilding, trust-building and connections activities at the beginning of each session, participants were able to identify connections, build on each others' strengths, and see the unit planning as part of a fun process.

\section{Connect to research and the PMSP theory of change on impacting teacher effective} instructional practices and student achievement in STEM.

The Portland Metro STEM Partnership developed a research-based theory of change on how to create a STEM learning experience for all students. This theory of change was new information for both the classroom teachers and the transportation professionals. By understanding the premise of the project through the theory of change and the project evaluation measures, participants were able to feel further investment into the process of doing something unique to impact student learning. The PMSP theory of change states:

If we want students to be successful in STEM majors and careers, then students need to acquire the conceptual knowledge, higher-order cognitive skills, and dispositions that are key outcomes associated with college and career readiness in STEM,

If we want students to be college and career ready in STEM, then learning environments must be characterized by the instructional practices, pedagogical content knowledge (specialized knowledge of teaching specific content), and supportive educator-student relationships,

The Portland Metro STEM Partnership supports educators in creating effective classroom environments by providing high quality STEM learning opportunities that focus on the implementation of effective instructional practices, pedagogical content knowledge and teacher self-efficacy. (See pdxstem.org for further information)

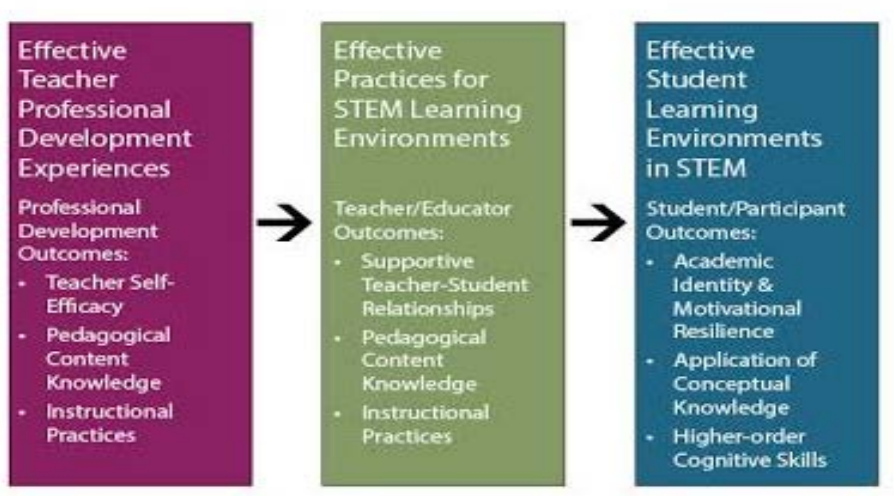

Figure 3.1: Portland Metro STEM Partnership Theory of Change 
The Investigations in Transportation project was directly aligned to providing the project participants with a high-quality STEM learning opportunity in order to increase effective instructional practices and pedagogical content knowledge. The grant coordinator and grant researcher were transparent about how each of the workshop sessions' activities and experiences connected to this theory of change.

\section{Do science and engineering as a group.}

In order to create a unit that inspired students to use critical thinking skills and apply conceptual understanding, the grant participants needed to experience doing science and engineering as a group. The grant coordinator took the participants through "studentcentered" tasks that modeled effective instructional practices that called on the use of higher-order thinking skills, scientific and engineering practices, and sense-making around science phenomenon and/or designing a solution.

\section{Harness the expertise in the group: Cultivate the professional knowledge and enthusiasm of transportation-sector STEM workers and the background and experience of classroom teachers.}

The lead teachers, transportation professionals and grant staff had a combination of over 60 years of classroom experience and over 50 years in transportation careers. Creativity, knowledge and expertise were all high-level assets. By identifying and appreciating the collective wisdom in the room, the group was able to build on ideas that in isolation by either the classroom teachers or the transportation professionals would never have happened.

\section{Develop shared understanding of Common Core and Next Generations Science Standards.}

The recent adoption of the Common Core State Standards (CCSS) for English Language Arts and Mathematics, along with the Next Generation Science Standards (NGSS), provided both parameters and exciting opportunities for what needed to be a part of the transportation unit. The standards were still relatively new to the lead teachers, and the transportation professionals had little or no understanding of what was expected of students at the fifth-grade level. The grant coordinator provided an extensive overview of the standards, not only to have a common understanding of the possible learning targets of the unit, but to develop a shared sense of the instructional shifts called for in the CCSS and NGSS for preparing 21st century college- and career-ready students.

6. Make connections to the real world.

One of the most exciting and energizing aspects of the initial workshop sessions was when the transportation professionals made connections between the education standards and direct or potential work in the transportation field. This generative idea-sharing experience provided a rich bank of unit themes, pathways, lessons and activities that had real-world relevancy, and opportunities for a high level of student engagement and transportation professionals working directly with students to support learning. The group created an Investigations in Transportation Unit Ideas and Themes Brainstorming List 
aligned to the fifth-grade math and science standards. The group also looked at other transportation-themed units to make connections and generate further ideas.

\section{Identify effective unit components.}

The Portland Metro STEM Partnership and Portland State University Center for Science Education have implemented previous teacher professional development grants resulting in unit development. The grant coordinator and grant researcher shared lessons learned from these experiences.

\section{Brainstorm possible dilemmas that lead to project selection.}

The NGSS have an increased focus on engineering design. By centering engineering design activities focusing on a "real-life" dilemma, students experience STEM with context and relevancy to learning. This is especially important for English Language Learners. The grant project participants brainstormed school-based, transportation-related problems that could be potentially solved by students and transportation professionals working together to create a solution. The team identified a parking lot dilemma, related to both reducing the traffic flow problems and safety issues.

\section{Support unit planning.}

After initial work with the transportation professionals on the Parking Lot Dilemma Unit, the lead teachers worked with grant staff and STEM TOSAs (Teachers on Special Assignment) to plan the unit. Though both schools have fairly similar sizes and demographics, the unit needed to have enough flexibility to address local school context. The team created a 24-session STEM Initial Investigations in Transportation Parking Lot Dilemma Unit addressing math and science standards with embedded literacy skills.

\subsection{UNIT IMPLEMENTATION}

September 2014 - March 2015: Grant funds provided substitute release for lead teachers to share units with colleagues. Funds were provided for purchasing transportation equipment, books and drafting supplies. STEM professionals worked with classroom teachers to implement aspects of these units in classrooms, giving students an opportunity to work with and become familiar with STEM professionals to whom they might otherwise not be exposed. Such exposure to STEM professionals, and to authentic real-world problems, gives students the opportunity to identify with and feel related to a STEM profession. This supported efforts to increase motivational resilience and academic engagement. 
Table 3.2: Unit Sharing and Implementation

\begin{tabular}{|c|c|c|c|}
\hline Session & Dates & Participants & Activities \\
\hline 1 & $\begin{array}{l}\text { Chehalem: August } 2014 \\
\text { Tobias: August } 2014\end{array}$ & $\begin{array}{l}\text { Lead Teachers } \\
\text { Collaborating } \\
\text { Teachers }\end{array}$ & Introduce Unit Premise \\
\hline 2 & $\begin{array}{l}\text { Chehalem: December } 2014 \\
\text { Tobias: December } 2014\end{array}$ & $\begin{array}{l}\text { Lead Teachers } \\
\text { Collaborating } \\
\text { Teachers } \\
\text { Grant } \\
\text { Coordinator }\end{array}$ & Unit Refinement and Revising \\
\hline 3 & $\begin{array}{l}\text { Chehalem: January } 2014 \\
\text { Tobias: January } 2014\end{array}$ & $\begin{array}{l}\text { Lead Teachers } \\
\text { Collaborating } \\
\text { Teachers }\end{array}$ & Lesson Planning \\
\hline 4 & $\begin{array}{l}\text { Chehalem: Late January 2015-Early } \\
\text { February } 2015 \text { (3 weeks) } \\
\text { Tobias: Mid-January 2015- Late } \\
\text { February } 2015 \text { (6 weeks) }\end{array}$ & $\begin{array}{l}\text { Lead Teachers } \\
\text { Collaborating } \\
\text { Teachers } \\
\text { Students }\end{array}$ & Unit Implementation \\
\hline
\end{tabular}

\subsubsection{Steps Taken to Bring Colleagues and Students on Board}

1. Share unit with teammates.

Through the use of grant funds, lead teachers and collaborating teachers had sub-release time to review the initial unit plan and identify how the unit would fit into the year's instructional plan.

\section{Revise unit and daily plans.}

Each school revised the unit and created daily lesson plans for implementing the unit. Collaborating teachers were able to provide additional instruction and resource ideas to the initial unit, along with identifying a school-specific pathway for implementation.

\section{Purchase equipment and resources.}

The NITC grant awarded funds to provide each school with resources and equipment to ensure an engaging and relevant experience for students. Schools purchased transportation-related literacy books, transportation measuring tools and devices, and blueprint materials, along with transportation equipment of hard hats and vests. These materials provided a direct connection to meeting the standards through transportationrelated activities, and brought authenticity to the unit for the students to see themselves as transportation engineers. 


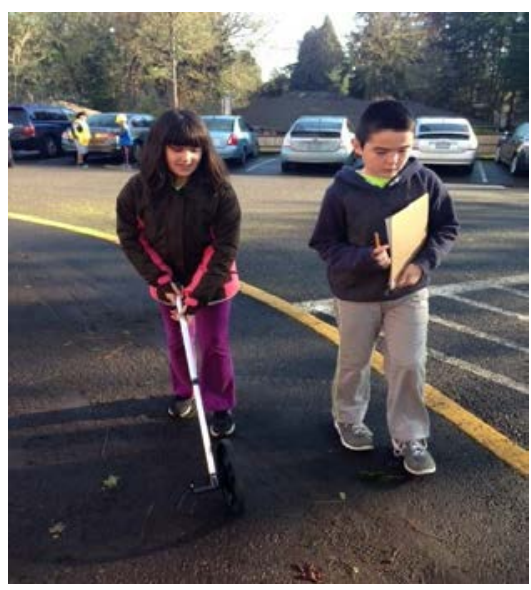

Figure 3.2: Chehalem students measure parking lot using grant-purchased equipment.

\section{Adjust the unit to meet schools' needs.}

Both schools adjusted the unit implementation from an original October-November time frame to a January-February time frame due to schedule constraints. Tobias Elementary created a plan for implementing the unit during science and math time for a six-week session. Chehalem planned for condensing the unit over three weeks, but integrating unit instruction throughout the whole day.

\section{Share unit with students: Engage.}

Fifth-grade students at Chehalem Elementary (three classrooms with 22-24 students per class) were taken on a tour of the school grounds and asked to notice areas that were problematic to both students and the community. Upon completion of the tour, students decided that the most impacted area of the campus was the parking lot. Teachers guided the students to focus on solving the parking lot dilemma. Two fifth-grade classrooms at Tobias Elementary with 22-24 students per class and a sixth-grade class of 35 students together determined that their parking lot was problematic as well. An investigation began to solve the parking lot dilemma for Tobias students and the community. Teachers at both schools shared the unit premise with students and explained about the grant opportunity. It was easy for students to buy into an idea that they saw as a true dilemma, and they were excited about connecting their classroom learning to real-life context.

6. Administer the pre-survey of academic identity and motivational resilience. The Portland Metro STEM Partnership has developed a student survey on academic identity and motivational resilience. This student survey can be used to inform decisions related to instructional strategies and the ability to create positive STEM learning environments. This key area was a focus of the grant. The student survey was given prior to the start of the unit in order to measure the impact of the Investigations in 
Transportation unit as an intervention for increasing student academic identity and motivational resilience.

7. Link STEM: science, technology, engineering and math through instruction to standards through project-based instruction.

Both schools are STEM schools; that is, they are creating a culture of STEM within the school, and creating genuine connections between instruction and STEM is part of the ongoing mission of a STEM school. Grant teachers identified ongoing opportunities for making the link between STEM and this project-based unit during all phases of the unit's implementation. Students interacted with the physical environment to aid in the group “dilemma” solution.

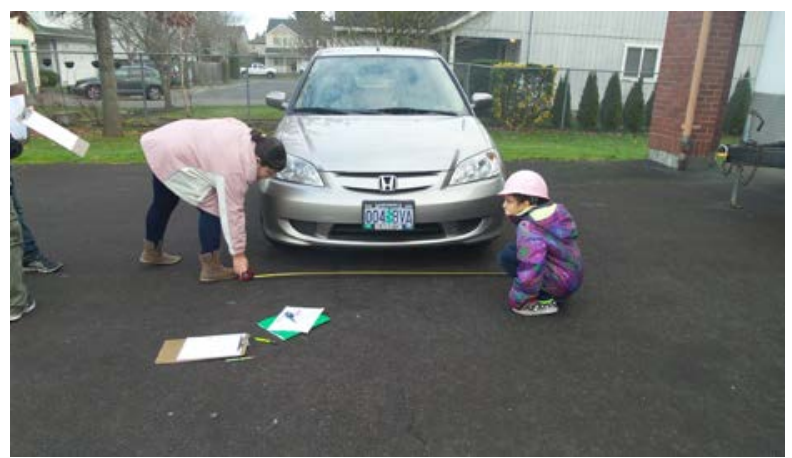

Figure 3.3: Tobias students use math skills to identify car dimensions.

\section{Share the excitement with parents.}

When students are actively engaged in learning and find personal relevance and meaning, they naturally want to share what is going on in the classroom with their family. Teachers sent home ongoing communication about the unit. Several of the activities required home involvement investigations, such as measuring the family's car and parking space dimensions. By creating a home-school connection, the unit took on a deeper level of meaning for students.

\section{Use transportation professionals for real-world, place-based connections, enthusiasm and expertise.}

Two of the transportation professionals who participated in the initial unit planning also volunteered at both Chehalem and Tobias schools to provide the link between actual transportation dilemmas, job roles/responsibilities and the school-based parking lot dilemma. Each of the transportation professionals volunteered their time for approximately eight hours at each of the schools. Anecdotal feedback from students, teachers and transportation professionals was very positive.

Transportation Professional Roles and Supporting Experiences Activities:

- Introduce themselves/connection with classes 
- Support for collecting initial parking lot traffic data

- Data analysis discussion support

- Video data analysis; real-life transportation dilemma connection

- Transportation professional project connection

- Parking lot redesign brainstorming support

- Blueprint design and presentation support

- Environmental impact of design support and consultancy
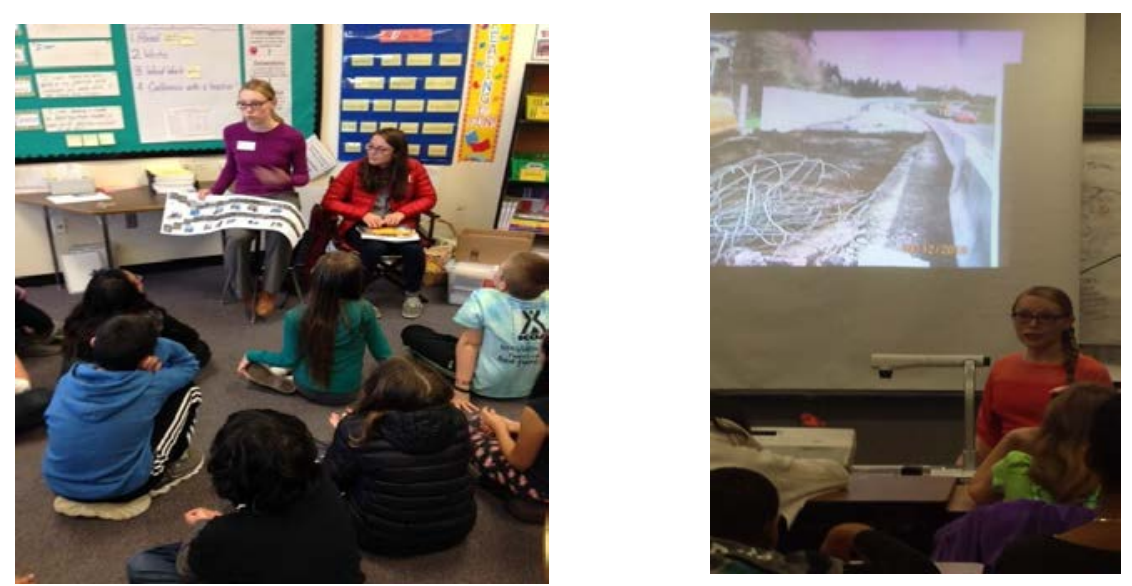

Figure 3.4: Transportation engineers share career connections to school parking lot dilemma.

\section{Engage students to collect and analyze data.}

Both the science and math standards require students to engage in critical thinking skills around the areas of collecting and analyzing data. The Investigations in Transportation unit required students to develop and utilize these skills throughout almost every session. Because of the hands-on, doing-the-actual-math-and-science nature of the activities, all students, regardless of their academic reading or math achievement level, were able to do these vital higher-level cognitive skills. Different groups collected different data, thus providing a sense of responsibility. All students engaged in relevant discussions to interpret the data and determine the implications of the data for solving the parking lot dilemma.

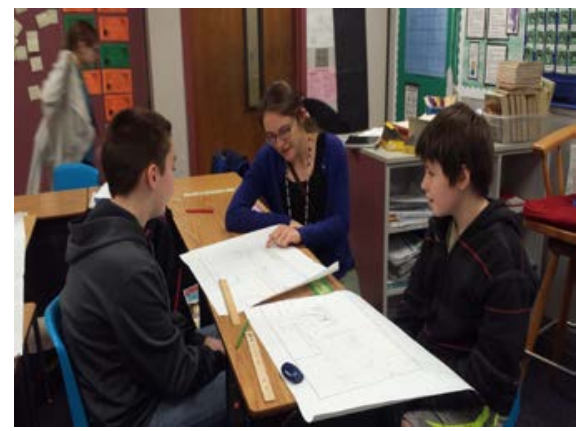

Figure 3.5: Chehalem students analyze and apply data to parking lot solutions.

\section{Create solutions to parking lot dilemma.}


Both schools had groups of students go through the engineering design process to define the problem around the situational constraints, develop possible solutions, optimize the solutions, and communicate their solutions to the rest of the class. At both schools, the student groups presented their solutions to district-level stakeholders consisting of facilities, safety, transportation, maintenance and community members. These stakeholders vetted the solutions and provided feedback about the feasibility and next steps for addressing the parking lot issues. Students were given opportunities to research, gather information and data and, finally, to prepare a small-group presentation. The end product or outcome was to persuade a group of stakeholders to make a "real-world" change to the current "dilemma" situation. The students created slideshows and presentation-boards and wrote essays to make their case.

For example, at Chehalem Elementary School student groups presented five possible solutions to the stakeholder team, which then selected the following three options for further consideration and review:

1) Determine who is coming by car and what part of our boundary they represent. (If they are driving to school, then the question is "why?" If we know that, we can try a resolution that addresses their motivation to drop off and pick up.)

2) Continue the work from three years ago to create viable walking paths for people on the other side of Murray Boulevard.

3) Determine the legal lengths and widths for parking spaces AND two lanes within the front lot.

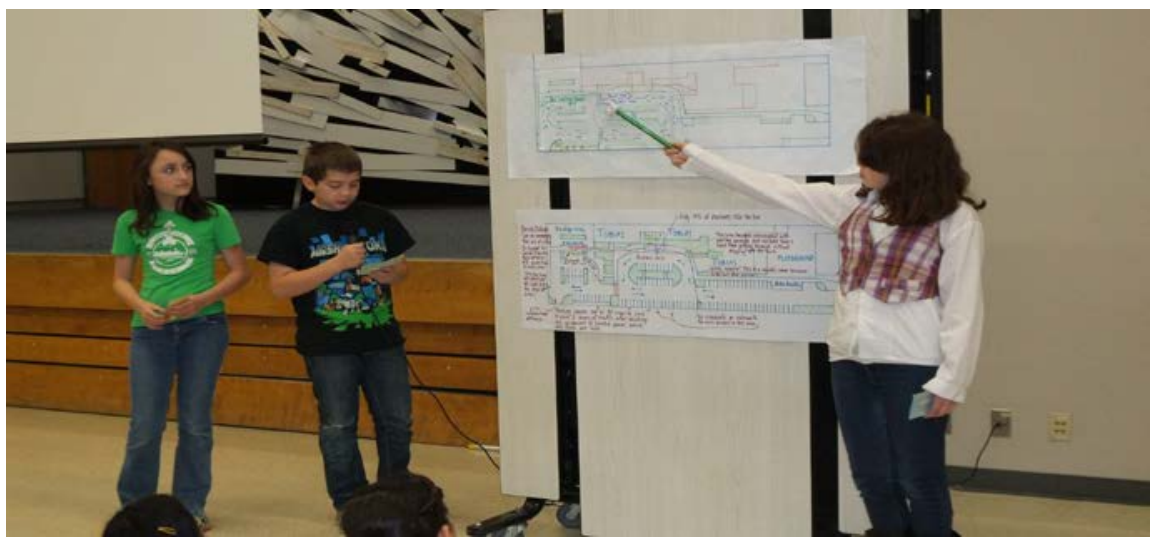

Figure 3.6: Tobias students present to stakeholders.

\section{Administer post-survey and application of conceptual knowledge task.}

At the end of the unit, the students took the post-survey (Academic Identity and Motivational Resilience). The students also completed a task that required the application of mathematical conceptual knowledge. The data from the pre/post surveys along with information about the student performance task is in the Evaluation section of this report. 


\section{STUDENT PERFORMANCE TASK}

In conjunction with the grant coordinator, teachers developed a Parking Lot Redesign task for assessing application of conceptual knowledge. This task had students apply their math knowledge and skills developed through the unit. This task was designed to reflect the performance tasks of the Smarter Balanced Assessment Consortium that measures student achievement of the Common Core State Standards for Mathematics.

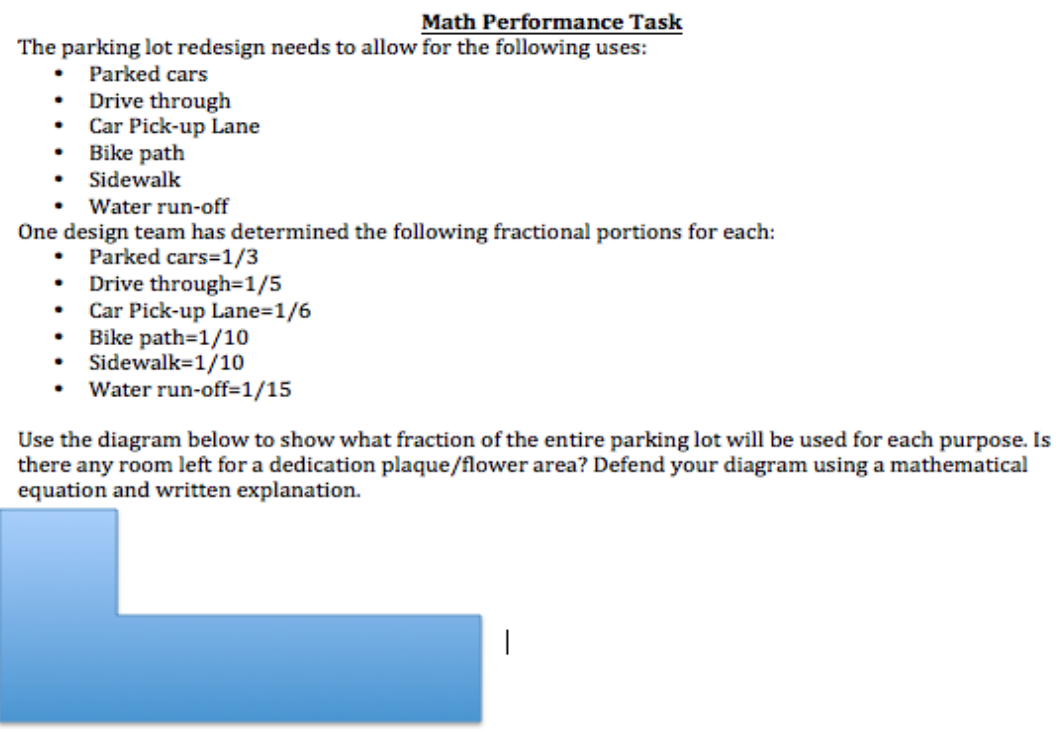

Figure 3.7: Performance task to assess application of conceptual knowledge.

\subsection{DATA REFLECTION}

Participating teachers were engaged in two data reflection opportunities described below. These opportunities were designed as professional development opportunities that also provided data for evaluating grant outcomes.

\subsubsection{Teacher Instructional Practices Reflection}

February-March 2015: As part of the PMSP Common Measures, the Teacher Instructional Practices (TIP) process allows for personalized professional growth reflection around instruction. Utilizing the partnership’s Teacher Instructional Practices rubric and data generated from classroom artifacts, the grant teachers at each school participated in reflection about the 
instructional decisions made during the unit implementation and the impact on student learning. The STEM School TOSAs facilitated the TIP process as a professional development experience focused on using data-driven information to support unit and instructional practices revisions. The data gathered was also used to evaluate grant outcomes.

\subsubsection{Cross Schools Collaborative Data Reflection Session}

Even though each school had its own pathway for implementing the unit, there was strong commonality with the experiences of the students. The grant evaluator took participants through a data reflection process looking at the student survey results, the TIP process reflections, and the student performance task successes and challenges. This experience was designed to be a learning process for the teachers and project staff to inform refinements and revisions to the unit itself, as well as for unit implementation and project replication. More information is in the Evaluation section of this report.

\subsection{PROJECT PARTNERSHIPS}

This project utilized partnerships to support all aspects of the workshops, unit development, unit implementation, and reflection process.

\subsubsection{Project Staff and Support Personnel}

- William Becker, Grant Principal Investigator

- Carol Biskupic Knight, Grant Coordinator and Co-Investigator

- Emily Saxton, Grant Researcher and Evaluator (January 2014-July 2014)

- Jerian Abel, PMSP Grant Evaluator (August 2014-December 2015)

- Melissa Dubois, Grant Partnership Liaison

- Erika Hansen, Chehalem STEM TOSA

- Leslie Smith-Mayfield, Tobias STEM TOSA

- Caitlin Everett, Beaverton Partnership TOSA

- Sandie Grinnell, Hillsboro Partnership TOSA

\subsubsection{Project Participants}

- Wendy Gould, Lead Teacher Chehalem Elementary

- Kristin Keezel, Chehalem Collaborating Teacher

- Marc Wildfang, Chehalem Collaborating Teacher

- Jennifer LeCorre, Lead Teacher, Tobias Elementary

- Cristina Cilberto, Tobias Collaborating Teacher

- Christ Campa, Tobias Collaborating Teacher

\subsubsection{Transportation Professionals}

- Tova Peltz, Project Manager, Oregon Department of Transportation

- Kristen Svicarovich, Transportation Engineering Consultant, DKS Associates 
- Pamela O'Brien, Transportation Engineering Consultant, DKS Associates

- Gwen Chambers, Transportation Engineering Consultant, Murray, Smith \& Associates

- Katie Freitag, Transportation Traffic Engineer, Oregon Department of Transportation

- Kelly Lautsen, Transportation Engineering Consultant, Kittelson \& Associates

- Ribeka Toda, Transportation Engineering Consultant, Kittelson \& Associates

\subsection{PROJECT FUNDING}

Grant funding supported grant staff buy-out for the project Principal Investigator, Grant Coordinator/Co-Investigator, Grant Researcher, Grant Partnership Liaison. Funds provided teacher stipends, substitute-release costs, conference travel, and materials and supplies.

Providing teachers with stipends and sub-release was critical for the extensive amount of time needed for unit development and reflection. 


\subsection{EVALUATION OF PROJECT OUTCOMES}

This project focused on educator and student outcomes, as described below.

\subsection{EDUCATOR OUTCOMES}

The project examined two educator outcomes:

\section{- Pedagogical Content Knowledge}

- Teachers' understanding and use of the effective strategies for specific STEM topics, including strategies to engage students in inquiry, represent STEM phenomena, and guide discourse about the STEM topic (Shulman, 1986).

During the unit development phase, growth in pedagogical content knowledge was tracked primarily through observation by the grant coordinator. According to the grant coordinator, teachers developed a deeper understanding of pedagogical content knowledge as they developed the unit. In particular, the grant coordinator noted an increase in the depth and real-world relevancy in the unit plan and a stronger alignment to standards. In addition, the unit has a high number of activities specifically designed to improve student engagement and motivation.

\section{- Effective Instructional Practices}

- Teachers will emphasize deep content knowledge and higher-order cognitive skills by addressing learning goals in these areas (Miner et al., 2010).

- Teachers will create and implement multiple and diverse opportunities for students to develop conceptual knowledge and cognitive skills (Stein, Smith, Henningsen \& Silver, 2009).

Effective Instructional Practices was assessed using data collected as part of the TIP reflective growth process. The Tobias team submitted one TIP packet of teaching artifacts for two of the teachers. The Chehalem team submitted individual packets (3) from each teacher. Each packet contained a combination of the following artifacts: 
Table 4.1 - Teacher Instructional Practices (TIP) process artifacts

\begin{tabular}{|c|c|c|}
\hline Component & Chehalem & Tobias \\
\hline \multicolumn{3}{|l|}{ Knowledge, Skills, Experiences } \\
\hline - Lesson plans without notes & & $\mathrm{X}$ \\
\hline - Lesson plans with notes & X X X & \\
\hline - Lesson handouts & $\mathrm{X}$ & $\mathrm{X}$ \\
\hline \multicolumn{3}{|l|}{ Assessments } \\
\hline - Student work samples rated H, M, L & & $\mathrm{X}$ \\
\hline \multicolumn{3}{|l|}{ - Student work samples not rated } \\
\hline \multicolumn{3}{|l|}{ - Formative or summative assessments } \\
\hline \multicolumn{3}{|l|}{ - Homework } \\
\hline - Rubrics & & $\mathrm{X}$ (TIPs) \\
\hline \multicolumn{3}{|l|}{ Teacher Reflections } \\
\hline $\begin{array}{l}\text { - Overall reflections related to pedagogical } \\
\text { practices }\end{array}$ & & $\mathrm{X}$ \\
\hline - Individual lesson reflection & $\mathrm{XXX}$ & $\mathrm{X}$ \\
\hline - Unit reflection & $\mathrm{X} X \mathrm{X}$ & $\mathrm{X}$ \\
\hline
\end{tabular}

The TIP rubric encourages examination of three instructional domains: Classroom Roles (student-centeredness), Content \& Cognitive Skills, and Use of Assessments. Table 4.2 below provides examples of teachers' reflections and their documented use of specific strategies in each of the domains. 
Table 4.2: TIP Process Results

\begin{tabular}{|c|c|c|c|}
\hline School & Classroom Roles & $\begin{array}{c}\text { Content and Cognitive } \\
\text { Skills }\end{array}$ & Assessments \\
\hline Chehalem & $\begin{array}{l}\text { The teacher was the facilitator } \\
\text { and usually delivered the } \\
\text { content. Students tried to do 'I } \\
\text { do, we do, you do' and also the } \\
\text { teacher gave them tasks to figure } \\
\text { out on their own. } \\
\text { The teacher listed } 6 \text { bullet points } \\
\text { under the heading 'student lead' } \\
\text { and } 8 \text { bullet points under the } \\
\text { heading 'teacher directed.' The } \\
\text { points were very specific } \\
\text { activities students and the } \\
\text { teacher completed, which clearly } \\
\text { illustrated their roles. For } \\
\text { example, student lead included } \\
\text { items such as group work and } \\
\text { research. Whereas teacher } \\
\text { directed included items such as } \\
\text { exit slips and create charts. }\end{array}$ & $\begin{array}{l}\text { The teacher did a mini } \\
\text { lesson on scaling, and } \\
\text { applied that to making the } \\
\text { maps. Students had } \\
\text { multiple opportunities to } \\
\text { practice scaling. } \\
\text { Generate and compare } \\
\text { multiple possible solutions } \\
\text { to a problem based on how } \\
\text { well each is likely to meet } \\
\text { the criteria and constraints } \\
\text { of the problem. } \\
\text { Students debate and } \\
\text { problem-solve issues, make } \\
\text { connections to current life } \\
\text { and real-world situations: } \\
\text { "We can work together to } \\
\text { come up with a viable } \\
\text { solution to a school } \\
\text { problem." }\end{array}$ & $\begin{array}{ll}\text { Formative examples } \\
\bullet & \text { Exit tickets } \\
\bullet & \text { Daily monitoring } \\
& \text { (observational) } \\
& \\
\text { Summative example } \\
\bullet & \text { Pre/post tests on } \\
& \text { content knowledge }\end{array}$ \\
\hline Tobias & $\begin{array}{l}\text { Students read survey data } \\
\text { independently, tallied survey } \\
\text { results and discussed them. The } \\
\text { teacher provided examples of } \\
\text { how to do each step in } \\
\text { interpreting, summarizing and } \\
\text { using the survey data. }\end{array}$ & $\begin{array}{l}\text { Strategies were well } \\
\text { documented and included } \\
\text { direct instruction, } \\
\text { modeling, independent } \\
\text { work, collaborative group } \\
\text { work, and reflection. } \\
\text { Students had multiple } \\
\text { opportunities to practice } \\
\text { converting fractions, } \\
\text { decimals and percentages } \\
\text { as well as calculating the } \\
\text { area of multiple spaces } \\
\text { using both whole numbers } \\
\text { and fractions. }\end{array}$ & $\begin{array}{l}\text { Teachers used formative } \\
\text { assessments. For example, } \\
\text { students created their maps and } \\
\text { parking analysis data. Teachers } \\
\text { stated they could informally } \\
\text { assess students' strengths and } \\
\text { weaknesses based on reviewing } \\
\text { their progress throughout the } \\
\text { lesson. }\end{array}$ \\
\hline
\end{tabular}

The lead teachers interviewed participating teachers about their experience on this grant and noted the following points:

- Both Chehalem and Tobias teachers were excited about the lessons and were pleased with the amount of student involvement and enthusiasm. Teachers commented on the fact that students were invested in the outcomes and were willing to work hard toward completion of group presentations. Parents were pleased to see that their students were 
“challenged" to help solve a "real-world problem” or dilemma.

- Teachers stated that, through the grant, students were able to use real-world tools and relevant text in order to enhance their learning and connections. Some journal entries were focused on building background knowledge and connecting with informational text.

- Teachers shared that teamwork is an important aspect of solving a dilemma. They felt that students learned that both at school and in the workplace, working together is essential. Additionally, teachers shared that as students gathered information and asked questions of the professionals, it created a sense of power to design their own solutions. When students met with professionals, the professionals brought both expertise and a "sense of authenticity" to students' work.

- Although all participating teachers were in agreement that both the process and the unit were worthwhile additions to the curriculum, the following improvements were identified.

- All teachers will be part of the refinement and delivery model decisions.

- Foundation lessons will be taught before the unit begins (e.g., measurement).

- Additional supplies and supports will be added to the unit.

- A stronger focus on Engineering Design and Math will be added.

- A stronger alignment with math and science standards is needed.

- Ongoing formative assessments will be used, including but not limited to quizzes.

While there is evidence of the incorporation and use of research-based instructional strategies, no plans were made to compare previously developed units to this transportation dilemma unit. Therefore, there is no way of knowing if teachers developed new skills in this area or simply incorporated known strategies effectively. The following areas of improvement are noted:

- Teachers may need additional training and support to better use stronger, more effective formative assessments.

- Individuals trained to facilitate the TIP process may need further or better guidance on the use of the TIP rubric.

- Teachers may need further guidance on the range and nature of artifacts to include in the reflection process, especially those associated with formative assessments.

\subsection{STUDENT OUTCOMES}

This project focused on two student outcomes, Motivational Resilience and Application of Conceptual Knowledge, as described below.

\section{- Student Outcome 1 - Motivational Resilience}

- Students will demonstrate high-quality participation in academic work, including hard work, resilience, enthusiasm and curiosity. Definition: Characterized by students' enthusiastic hard work and persistence in the face of challenging STEM coursework; includes components of academic engagement and constructive 
coping/persistence. Rationale: Whole-hearted engagement and tenacity in demanding STEM classwork is essential to student learning and achievement.

(Furrer \& Skinner, 2003; Skinner, Kindermann \& Furrer, 2009).

Motivational resilience was assessed as a pre/post measure utilizing the PMSP's Student Affective Survey in math. The pre-survey was administered to students prior to unit implementation, and the post-survey was administered within one to two weeks after the end of the unit. The survey includes subscales on academic identity and motivational resilience. While data is reported for both scales, the project's intent was to focus on motivational resilience because academic identity usually requires a longer intervention. Tables 4 and 5 show the results for Tobias Elementary School and Chahelam Elementary School, respectively. The survey utilizes a 5 -point scale ( $1=$ not at all true to $5=$ totally true). Percent (\%) Optimal is the percentage of students responding with a 4 or 5 .

Table 4.3 - Aggregate results for Tobias Elementary School

\begin{tabular}{c|c|c|c|c|c|c}
\hline & & \multicolumn{2}{|c|}{ Academic Identity } & \multicolumn{2}{c}{ Motivational Resilience } & \% Optimal \\
\hline$* 3$ teachers & $\mathrm{N}=$ & mean & \%opt. & mean & \%opt. & (all items) \\
\hline PRE (Fall 2014)* & 77 & 3.9 & $68 \%$ & 4.0 & $70 \%$ & $69 \%$ \\
\hline POST (Feb. 2015)* & 79 & 3.7 & $62 \%$ & 3.9 & $68 \%$ & $65 \%$ \\
\hline
\end{tabular}

Sub-Scales Results (mean)

\begin{tabular}{c|c|c|c|c|c|c|c}
\hline & \multicolumn{5}{|c|}{ Academic Identity } & \multicolumn{2}{l}{ Motivational Resilience } \\
\hline & Identity & Relatedness & Competence & Autonomy & Purpose & Engagement & Coping \\
\hline PRE & 3.6 & 3.8 & 4.1 & 3.8 & 4.1 & 4.0 & 3.9 \\
\hline$\%-O p t i m a l$ & $59 \%$ & $68 \%$ & $73 \%$ & $64 \%$ & $74 \%$ & $72 \%$ & $69 \%$ \\
\hline POST & 3.4 & 3.3 & 4.0 & 3.6 & 4.1 & 4.0 & 3.7 \\
\hline$\%-O p t i m a l$ & $52 \%$ & $51 \%$ & $73 \%$ & $59 \%$ & $74 \%$ & $71 \%$ & $64 \%$ \\
\hline
\end{tabular}


Table 4.4 - Aggregate results for Chehalem Elementary School

\begin{tabular}{|c|c|c|c|c|c|c|}
\hline & \multirow[b]{2}{*}{$\mathbf{N}=$} & \multicolumn{2}{|c|}{ Academic Identity } & \multicolumn{2}{|c|}{ Motivational Resilience } & \multirow{2}{*}{$\begin{array}{c}\text { \% Optimal } \\
\text { (all items) }\end{array}$} \\
\hline & & mean & \%opt. & mean & \%opt. & \\
\hline $\begin{array}{l}\text { PRE (Fall 2014) } \\
\text { (2 teachers) }\end{array}$ & 41 & 3.9 & 69 & 3.9 & 71 & 70 \\
\hline $\begin{array}{c}\text { POST (Feb. 2015) } \\
\text { (3 teachers) }\end{array}$ & 61 & 3.7 & $61 \%$ & 3.8 & $67 \%$ & $64 \%$ \\
\hline
\end{tabular}

Sub-Scales Results (mean)

\begin{tabular}{c|c|c|c|c|c|c|c}
\hline & \multicolumn{4}{|c|}{ Academic Identity } & \multicolumn{2}{c}{ Motivational Resilience } \\
\hline & Identity & Relatedness & Competence & Autonomy & Purpose & Engagement & Coping \\
\hline PRE & 3.8 & 4.0 & 3.7 & 3.7 & 4.4 & 4.1 & 3.8 \\
\hline$\%$-Optimal & $63 \%$ & $72 \%$ & $68 \%$ & $62 \%$ & $80 \%$ & $76 \%$ & $66 \%$ \\
\hline POST & 3.6 & 3.2 & 3.8 & 3.6 & 4.2 & 4.1 & 3.6 \\
\hline$\%$-Optimal & $58 \%$ & $48 \%$ & $69 \%$ & $59 \%$ & $75 \%$ & $73 \%$ & $60 \%$ \\
\hline
\end{tabular}

Results are mostly flat (little to no change in means, little change in percentage optimal rates) for motivational resilience; therefore, no conclusions can be made. Lack of results may be attributed to the intervention being too short and/or the pre- and post-survey contexts being dissimilar. For instance, if the post-survey was administered during the same time as when standardized tests were taken, students may have experienced "test fatigue" and answered the survey without due consideration to the questions.

\section{- Student Outcome 2 - Application of Conceptual Knowledge}

○ Students know how to apply math conceptual knowledge to solve problems, including scientific inquiry and engineering design.

Data was collected as a post-only activity. As described in Section 3.3, the teachers developed a Parking Lot Redesign task to assess the students’ ability to apply conceptual knowledge.

Teachers were asked to bring nine student work samples (three each) that they scored as high, medium and low based on the PMSP Application of Conceptual Knowledge rubric. The grant 
evaluator was to score a subset from each classroom as part of this analysis. However, not enough teachers submitted samples to make this a viable approach.

\section{Additional Data}

Participating teachers asked their students "What did you most enjoy about the Parking Lot Dilemma Project?” and captured the following reflections:

Chehalem students

- "The most fun part was getting to use the measuring tools."

- "I enjoyed measuring the parking lot with my team."

- "I liked working with my team on the presentation job."

- " Presenting to the principal and the stakeholders was FUN!"

- "Being able to work as a team was so much fun!"

Tobias students

- "The professionals were very helpful."

- "I enjoyed measuring the cars with the measuring wheel."

- "It was fun working in partnerships."

- "I enjoyed the process because the professionals gave us key points."

- "It was a fun learning experience."

Teachers participating in the Data Reflection Session discussed the unit planning process, examined the student survey results, and shared reflections on the TIP reflective growth process as well as challenges related to assessing students' application of conceptual knowledge. Overall, the teachers agreed on four areas of success:

- The authentic learning experiences were critical to the unit's success.

- Students demonstrated higher levels of engagement compared to other units or learning experiences.

- Students benefited from opportunities to learn from each other.

- Placed-based learning, in this case at the school itself, results in higher levels of ownership and relevancy for both the teachers and the students.

The teachers also noted the following challenges:

- There was not enough time to fully develop, implement and revise the unit and associated lesson plans.

- The timing and nature of the PMSP student surveys may not have provided useful data.

- Designing a strong “application of conceptual knowledge” task is challenging. 


\subsection{PARTNERSHIP/PROGRAM OUTCOMES}

As part of the grant, evaluating the professional development plan for both project efficacy and replication was an important step.

The lead teachers were very enthusiastic about the unit plan they created. The connection to the transportation professionals, the real-world transportation challenge, and the opportunity for students to make a difference in their school community through solving a parking lot dilemma is providing high hopes for significant levels of student engagement and conceptual understanding. The collaborating teachers at both schools share that excitement. They feel that the real-life relevancy will motivate students to want to learn the concepts and skills in order to actually solve their parking lot problem.

The lead teachers have also stated that the higher-order thinking skills that the unit develops (and having actual transportation professionals share how these skills, along with the mathematical and scientific knowledge, are used in their jobs) will have an impact on student success.

The teachers themselves have shared that they look at transportation issues through a much different perspective because of their involvement in planning the unit.

The bond that developed between the transportation professionals who helped plan the unit and the lead teachers was very strong. The transportation professionals' expertise informed context and content, and impacted the choice of activities for the unit. Their expertise also furthered the teachers' understanding of the math and science as demonstrated by the lesson selection and unit flow. Two of the transportation professionals who participated in the unit planning worked directly with students during unit implementation.

\subsection{PROJECT STRENGTHS, CHALLENGES AND LESSONS LEARNED}

\subsubsection{Project Design}

Strengths: Clear, cohesive plan; unique premise of direct partnership with transportation professionals; collaborative nature of professionals, teachers, researchers, and curriculum specialists

Challenges: Change in grant researcher; loss of Partnership Liaison in May of 2014; school scheduling and conflicting priorities; gaps in project work; mentor training cancelled because of limited number of transportation professionals recruited for actual classroom support and loss of Partnership liaison.

Lessons Learned: Maintain timeline

\subsubsection{Project Partnerships}

Strengths: Strong STEM connections; variety in transportation agencies; volunteered hours. Challenges: Only female engineers; limited number of volunteers for school site due to timing. Lessons Learned: Provide extensive amount of time for recruiting of volunteers. 


\subsubsection{Unit Development}

Strengths: Engaging, student-centered, standards aligned unit; high quality. Challenges: Tedious, time-consuming process; unit development fatigue after three-hour session; one lead teacher not available during summer for unit development work; the intense planning of the unit with the connections to standards in several subjects and transportation context took longer than originally planned. The unit was not ready for sharing with the collaborating teachers in August 2014 as originally planned. Additional unit planning sessions were done in September 2014. Assessment was not addressed strongly enough. This likely impacted student Application of Conceptual Knowledge task outcomes.

Lessons Learned: Build in enough unit development time over a concise but ongoing time span; build in time for grant coordinator to be part of school-based revisions. Strengthen formative assessment development opportunities.

\subsubsection{Unit Implementation}

Strengths: Creative pathways; high level of student engagement.

Challenges: Due to the scheduling and other teaching demands, the unit implementation was not able to happen in fall of 2014 and was moved to January-February 2015, resulting in a loss of momentum. The gap from Fall term to Winter term. Gap from when unit was initially reviewed and implementation caused some confusion related to activity purpose, and also delayed recruitment of transportation professionals. Lessons Learned: Make unit implementation a priority.

\subsubsection{Project Dissemination}

Strengths: NSTA presentation to educators was well received.

Challenges: Limited dissemination to transportation professionals; lead teachers lacked skill set to bring unit to scale for a higher level of dissemination. Momentum was lost between main project work to next step dissemination.

Lessons Learned: Prioritize dissemination.

\subsubsection{Project Evaluation}

Strengths: PMSP Common Measures, TIP process.

Challenges: Change in grant researcher and lack of role clarity; original evaluation plan did not align to intervention timeline realities; a moderation and calibration session on the student performance tasks as part of the data reflection process did not happen due to the timing of the completion of the unit implementation and lack of sufficient time for participating teachers, grant coordinator and grant evaluator. Teachers did not provide enough student work samples for analysis.

Lessons Learned: Prioritize evaluation by creating realistic time lines that can be adjusted based on changing circumstances; clearly articulate roles and responsibilities of project staff when evaluation activities are embedded as professional development opportunities; and develop 
mechanisms for better communication with participating teachers regarding evaluation expectations.

\subsection{RECOGNITION AND DISSEMINATION}

\subsection{NATIONAL SCIENCE TEACHER ASSOCIATION CONFERENCE}

March 12, 2015: Lead teachers and the grant coordinator presented the unit at the Chicago NSTA conference. (Conference Planning: February-March 2015)

\subsection{BEAVERTON SCHOOL BOARD RECOGNITION}

The Beaverton School Board recognized the Chehalem grant teachers and project coordinator of the Investigations in Transportation Parking Lot Dilemma at their April $27^{\text {th }}$ meeting as an exemplar of the district's Pillar of Innovation.

\subsection{TREC NEWSLETTER}

Lacey Friedly, TREC Communications Coordinator, interviewed the Tobias and Chehalem lead teachers along with the grant coordinator, and posted the Investigations in Transportation news piece on the TREC website.

\subsection{UNIT REFINEMENT}

Lead teachers and the school-based STEM Teachers on Special Assignment provided initial work on refining the unit. Cristina Trecha, a curriculum developer out of the Center for Science Education, was charged with further unit refinement in order to bring it to a more accessible level for classroom teachers. (Teacher Refinement: June 2015) 


\subsection{WEBINAR}

A spring 2016 webinar will be held for both transportation professionals and classroom teachers who want to find out more about the project as a whole in order to create a similar experience. 


\subsection{APPENDICES}

\section{APPENDIX A NSTA PROPOSAL}

Proposal submitted for the 2015 National Science Teachers Association (NSTA) Conference in Chicago on Investigations in Transportation was accepted. The need for integrated, applicable units in STEM is high, especially at the elementary level. The audience for the conference was classroom teachers and STEM leaders from all across the country.

Abstract is below:

Investigations in Transportation: Partnering Industry Professionals and Elementary Teachers in a STEM Unit of Study

Investigations in Transportation program, an elementary school partnership and curriculum development project, engages STEM professionals in school-based design projects bringing realworld applications to elementary classrooms.

The Investigations in Transportation session shares the process and exemplar instructional unit created through a partnership that harnessed the professional expertise, experience and enthusiasm of transportation-sector STEM workers with elementary teachers. Through a collaborative partnership and using a set of protocols, transportation professionals engaged with elementary school teachers to develop and implement an instructional unit that allowed students to explore and investigate issues central to transportation. The exemplar unit incorporates and enhances the content and practice standards outlined by the Common Core State StandardsMathematics and Next Generation Science Standards, and relied heavily on the expertise and experience of classroom teachers to develop an age- and interest-appropriate unit of study. This collaboration resulted in the development of an Investigations in Transportation instructional unit that provided students with rich, engaging learning opportunities set in the context of real-world problems of sustainability, health and safety. Participants in the session will receive access to the exemplar unit, including activities, lesson plans, student assessments, and description of the Common Core and NGSS standards/strands addressed. A draft of the protocols for facilitating collaboration between elementary school teachers and STEM professionals to develop meaningful, authentic instructional units that address real-world STEM problems will also be shared. 


\section{APPENDIX B GRANT FUNDS ALLOCATION}

\begin{tabular}{|c|c|}
\hline $\begin{array}{l}\text { Participant Support } \\
\text { Funds For: }\end{array}$ & Purpose \\
\hline Lead Teacher Stipends & $\begin{array}{l}\text { Stipends for } 5 \text { workshops; unit collaboration; } \\
\text { serving as point of contact for STEM volunteers } \\
\text { during implementation; data collection and unit } \\
\text { implementation }\end{array}$ \\
\hline $\begin{array}{l}\text { Collaborating Teacher } \\
\text { Stipends }\end{array}$ & Stipend for data collection and unit implementation \\
\hline $\begin{array}{l}\text { Lead Teacher Travel to } \\
\text { Conference }\end{array}$ & $\begin{array}{l}\text { Lead teachers presented their work at a national } \\
\text { educator conference. Budget for: } \\
\text { - Conference registration } \\
\text { - Conference preparation } \\
\text { - Related travel/lodging } \\
\text { - Sub-release }\end{array}$ \\
\hline $\begin{array}{l}\text { Sub-release Time for } \\
\text { Teachers }\end{array}$ & $\begin{array}{l}\text { - } 6 \text { teachers for grade-level collaboration and } \\
\text { unit planning (Fall 2014) } \\
\text { - } 6 \text { participants for unit evaluation workshop } \\
\text { (Spring 2015) }\end{array}$ \\
\hline Materials and Supplies & Allowance for transportation unit-related materials \\
\hline
\end{tabular}




\section{APPENDIX C UNIT MATERIALS}

\section{LIST OF UNIT MATERIALS PURCHASED}

\section{Equipment:}

- Engineering is Elementary The Attraction is Obvious MagLev Unit Kit

- 3 sets of Legos, Lego 4026 Creator Build and Imagine 100 pcs.

- 18 Hard hats (6 per class), Jackson Safety Sentry III Yellow High Density Polyethylene Cap Style HardHat - 6-Point Suspension - Ratchet Adjustment - Accessory Slots

- 75 folders (2 pockets),

- 18 measuring tapes Lufkin L625SCTMP 1-Inch by 25-Feet Hi-Viz Self Centering Orange Power Return Tape

- 75 sheets of Blueprint paper, on Amazon Blueprint Paper 12"X12"- 25 per pack

- 3-Large sticky poster paper pads with 1 in. grid,

- 6 surveyors wheels: TBC "BIG" Measuring Wheel: 10,000 Ft Walking Measuring Wheel

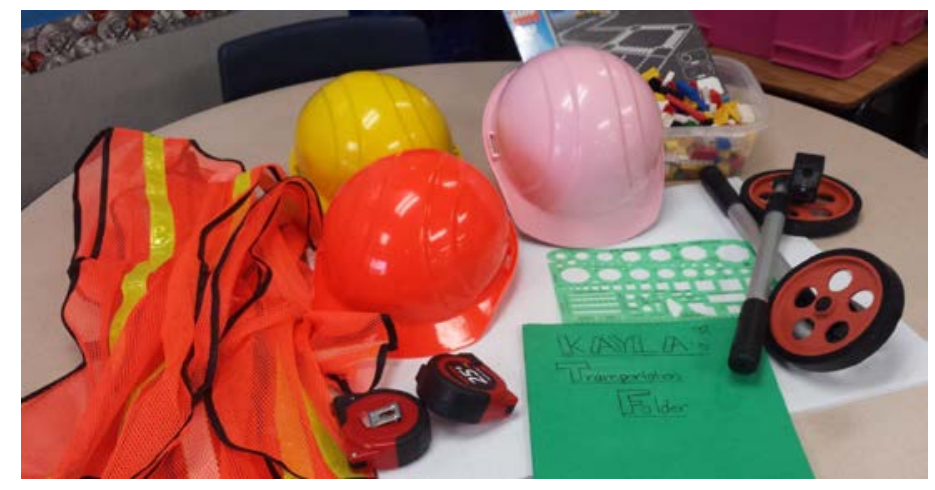

\section{Literacy Books:}

- Terrific Transportation Inventions (Awesome Inventions You Use Every Day) by Laura Hamilton Waxman

- Honda: The Boy Who Dreamed of Cars, Mark Weston

- Henry Ford: Young Man with Ideas (Childhood of Famous Americans),

- Time for Kids:Henry Ford (Time for Kids Biographies)

- The Impact of Environmentalism--Transportation paperback

- Hybrid Cars (A Great Ideas Series)

- Electrifying Eco-Race Cars (Fast Rides)

- How Electric Cars ad Hybrids Work (Ecoworks (Gareth Stevens))

- A Head Full of Notions: A Story about Robert Fulton (Creative Minds Biography) Munford Meets Robert Fulton 
- What Was the Hindenburg?

- Who Was Amelia Earhart?

- Who Was Henry Ford?

- Who Were the Wright Brothers?

- Who was Neil Armstrong?

- Who was Sally Ride?

- Explore Transportation!: 25 Great Projects, Activities, Experiments (Explore Your World series) by Marylou Morano Kjelle

- Rosie Revere Engineer

- If I Built a Car by Chris Van Dusen Hardcover

- Modes of Transportation: ABC Book of Rhymes: Children's Picture Book by Yael Rosenberg

- Gas Trees and Car Turds: Kids' Guide to the Roots of Global Warming by Kirk Johnson

- Honda: The Boy Who Dreamed of Cars by Mark Weston

- We're Riding on a Caravan by Laurie Krebs

- This Is the Way We Go to School: A Book About Children Around the World by Edith Baer

- Let's Get Moving: Modes of Transport Through The Ages by Dr. Stephanie R. Dillon Transportation Inventions: From Subways to Submarines (Which Came First) by Sandra Will

- An Illustrated Timeline of Transportation (Visual Timelines in History) by Kremena T.Spengler

- Car Science by Richard Hammond \$13.99 (1copy)

- Terrific Transportation Inventions (Awesome Inventions You Use Every Day) by Laura Hamilton Waxman

- This Is the Way We Go to School: A Book About Children Around the World by Edith Baer, Steve Bjorkman

- An Illustrated Timeline of Transportation (Visual Timelines in History) by Kremena T. Spengler, Eldon Doty

- Tomorrow's Transportation: Green Solutions for Air, Land, \& Sea (New Careers for the 21st Century: Finding Your Role in the Global Renewal) by Malinda Miller

- Here Comes the Garbage Barge! Hardcover by Jonah Winter

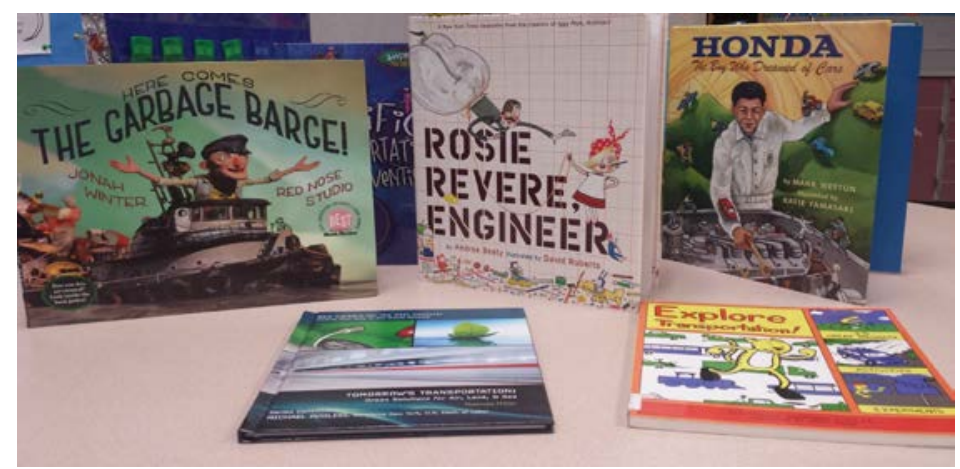


STEV PORTLAND METRO
STEM PARTNERSHIP

Investigations in Transportation:

Partnering Industry Professionals and

Elementary Teachers in a Targeted

STEM Unit of Study

\section{Portland State}




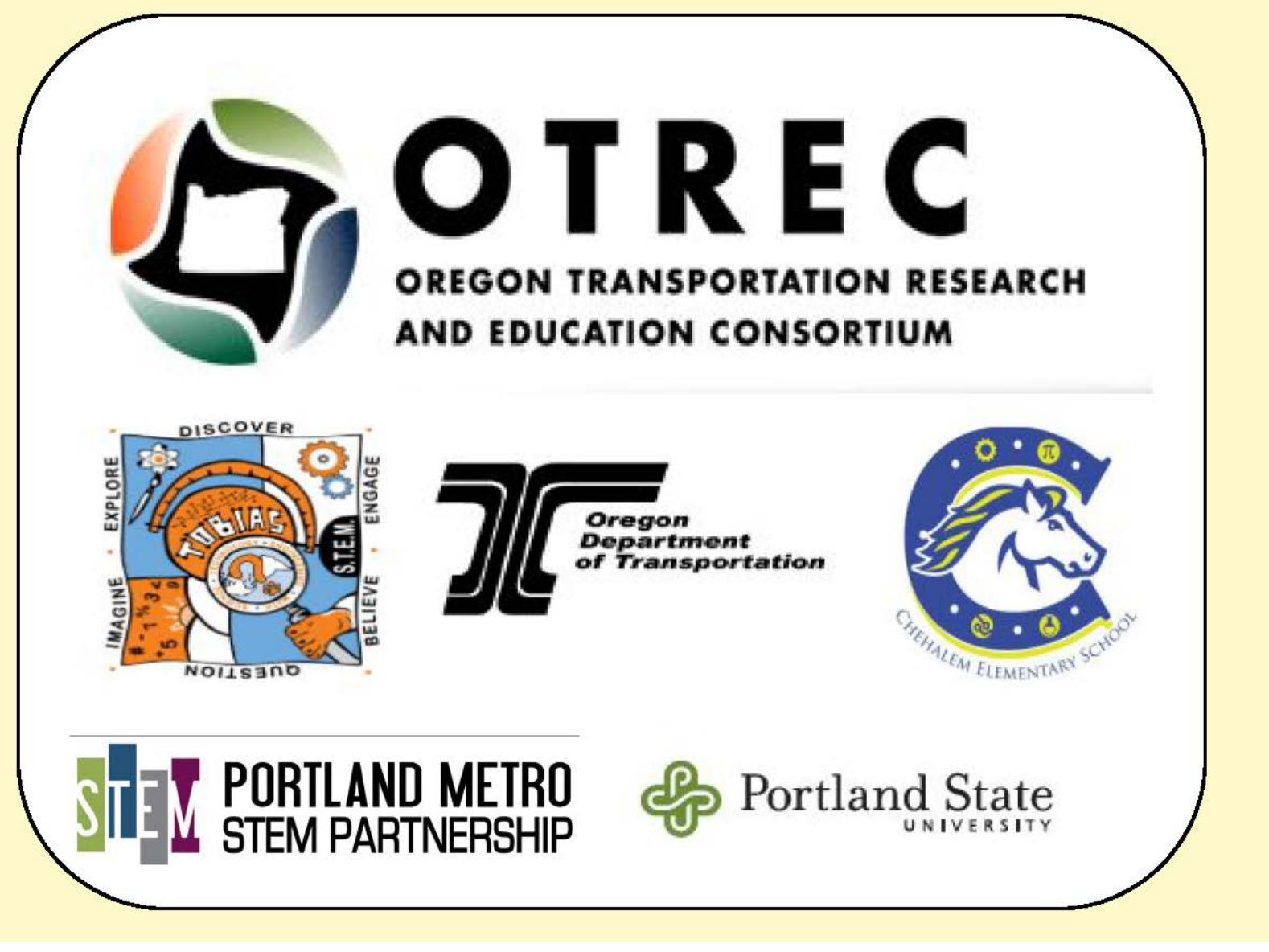




\section{Presenters' Background}

Carol Biskupic Knight:

- 34 years in education as classroom teacher and curriculum specialist

- PMSP Director of STEM Teachers Academy

Wendy Gould:

- teaching for 20 years

- past 15 years at Chehalem, BSD

- Title 1 STEM school

Jennifer LeCorre:

- teaching for 20 years at Tobias Elementary, HSD

- STEM school

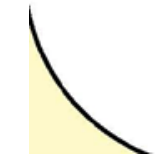




\section{Grant Premise and Participants}

A Collaborative Partnership for Creating a PlaceBased Standards Aligned Interactive Unit

Through an Oregon Transportation and Research Consortium Grant, the Elementary Investigations in Transportation project harnessed the professional expertise, experience, and enthusiasm of transportation sector STEM workers by creating a mechanism and set of protocols by which they engaged with elementary school teachers to develop and implement an instructional unit. This STEM connected instructional unit and lessons allowed students to explore and investigate issues central to transportation. 


\section{Session Focus}

- Share the process for unit development while creating partnerships to connect the various aspects of standards based work and a placebased context using grade level content

- Provide resources for replicating the process 


\section{Parking Lot Dilemma}

Fifth grade students at Chehalem Elementary (three classrooms with 22-24 students per class) were taken on a tour of the school grounds and asked to notice areas that were problematic to both students and community. Upon completion of the tour students decided that the most impacted area of the campus was the parking lot. Hence, the "Parking Lot Dilemma" was created.

Two fifth grade classrooms at Tobias Elementary with 22-24 students per class and one sixth grade class of 35 students together determined that their parking lot was problematic as well. So an investigation began to solve the "Parking Lot Dilemma" for Tobias students and the community.

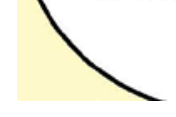



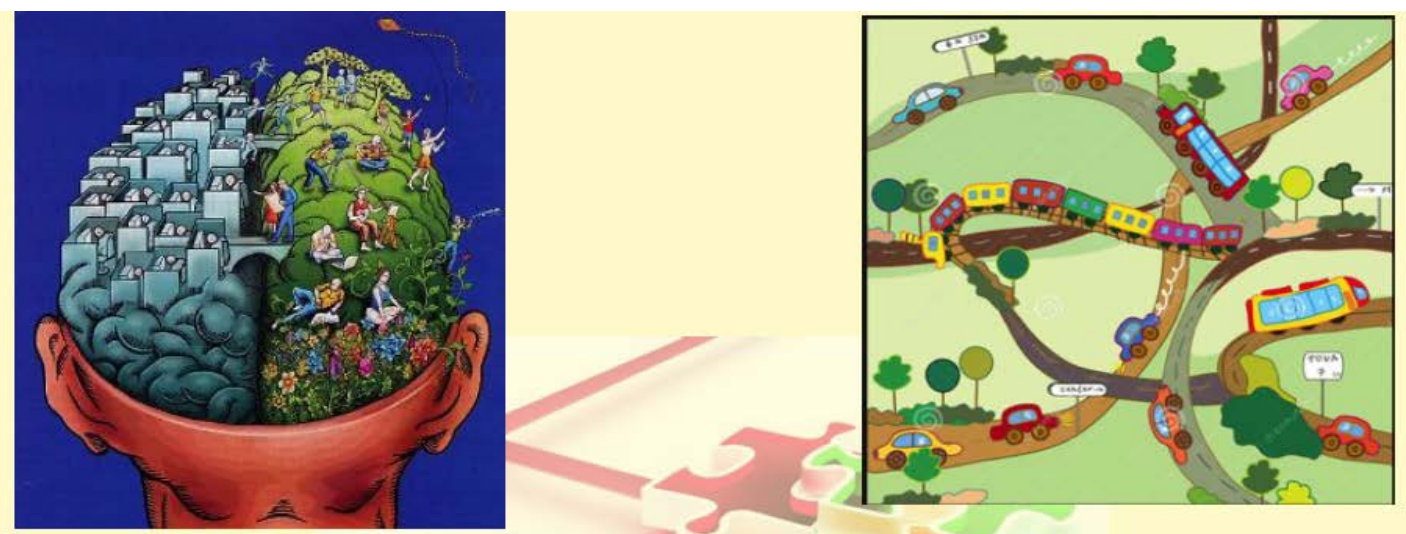

Part 1: Investigations in

\section{Transportation: Planning Process}
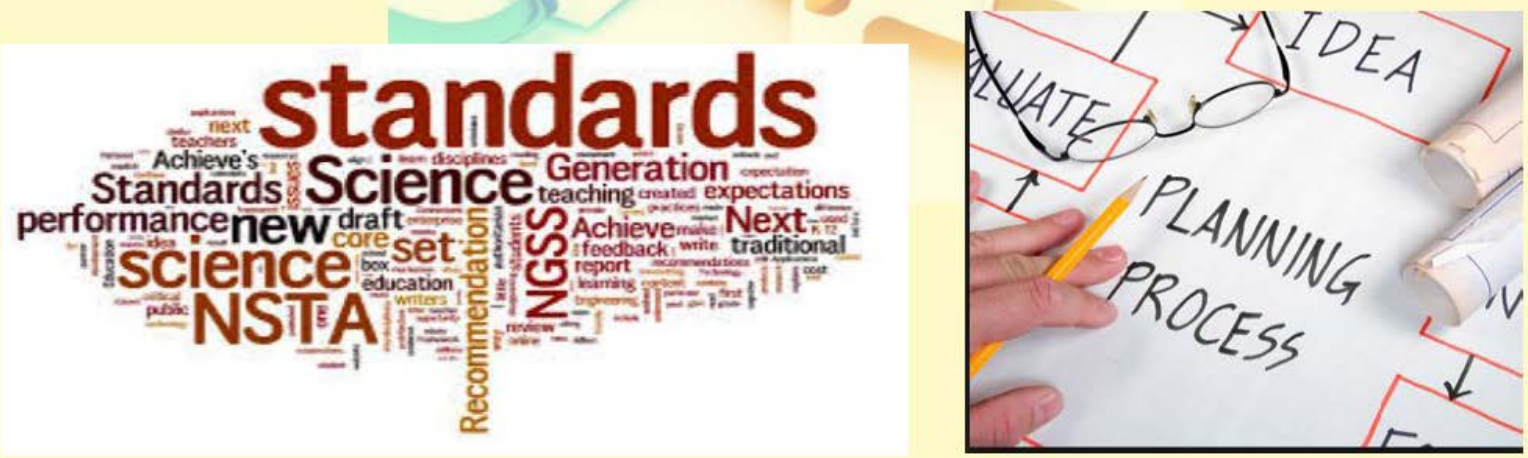


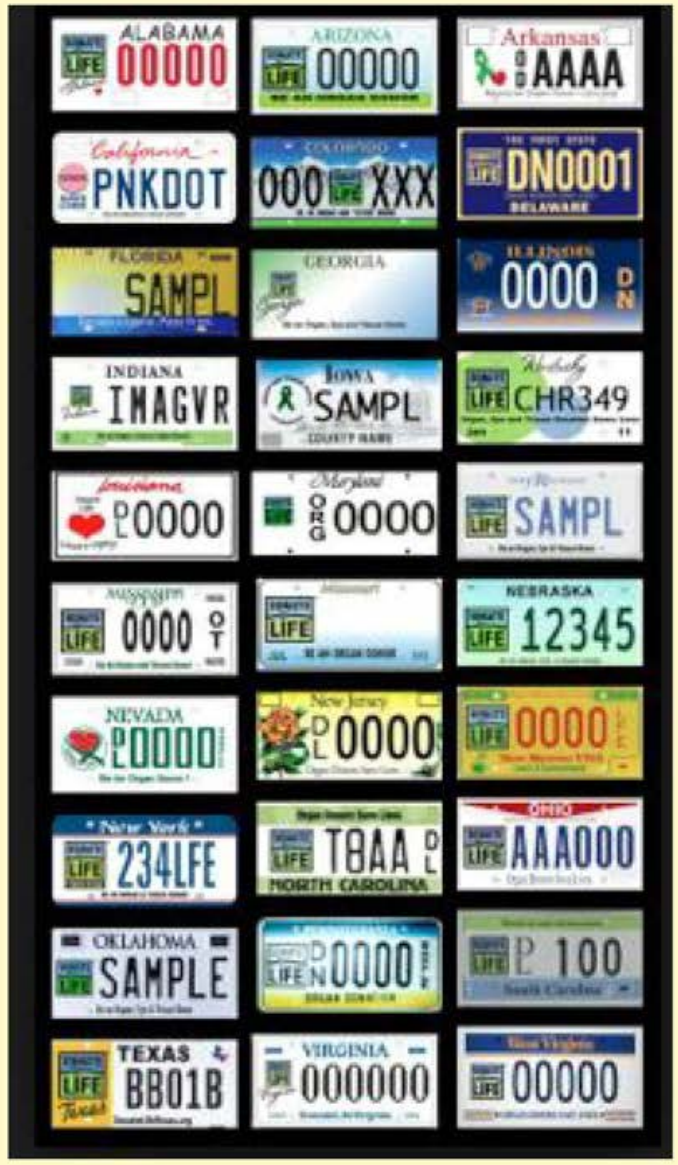

\title{
Initial Planning:
}

\author{
Building \\ Relationships, trust \\ and a shared sense \\ of community
}


A person you admire or would like to be like
Someplace you've been and didn't want to leave

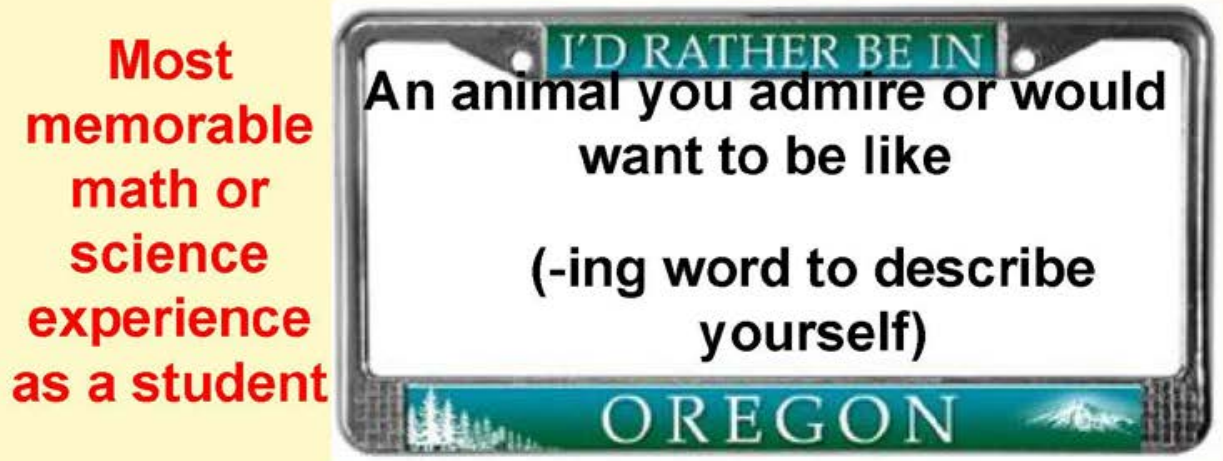

Experience or person that affected your career decision
If you had two hours to do anything with no limits what would you do?
What do you see yourself doing in 10 years? 


\section{Connection to Research}

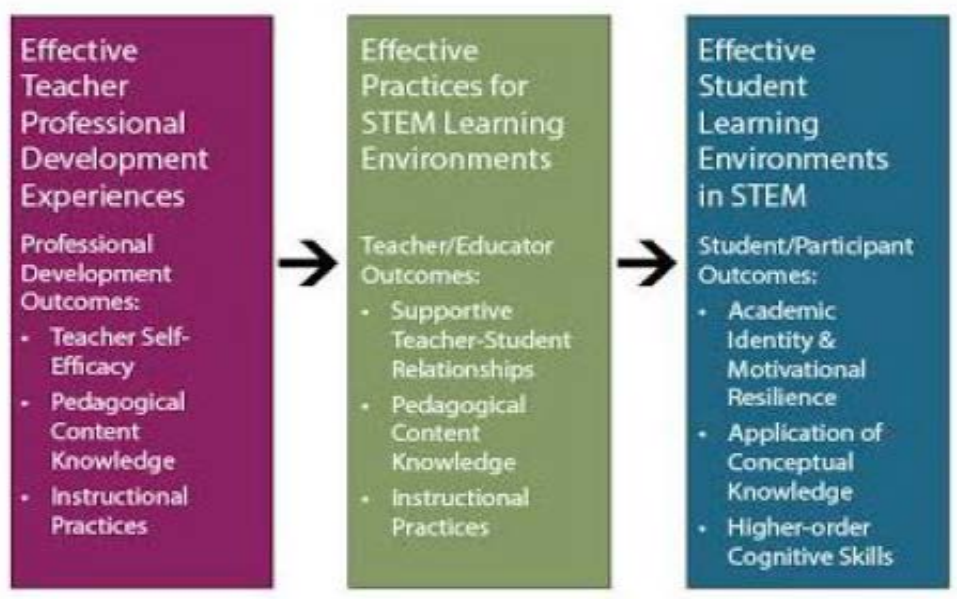

\section{Theory of Change Diagram}




\section{Grant Goals: Connection to Standards}

Teacher Effective Instructional Practices:

-Emphasize deep content knowledge and higher order cognitive skills by addressing learning goals

- Create and implement multiple and diverse opportunities for students to develop conceptual knowledge 


\section{Grant Goals: Connection to Strategies}

Teacher Pedagogical Content Knowledge:

Understanding and use of the effective strategies for math and engineering design

Making connections within the content to all areas of the grade level curriculum

Showing learners the "real-world" connections 


\section{Grant Goals: Student Outcomes}

Student Academic Identity and Motivational Resilience $\sim$ Characterized by students' enthusiastic hard work and persistence in the face of challenging STEM coursework

Application of Conceptual Knowledge Students' understanding and thinking about ideas, theories and perspectives considered critical within an academic discipline.

Creating Effective STEM Learning environments 


\section{Connecting and Inspiring: STEM}

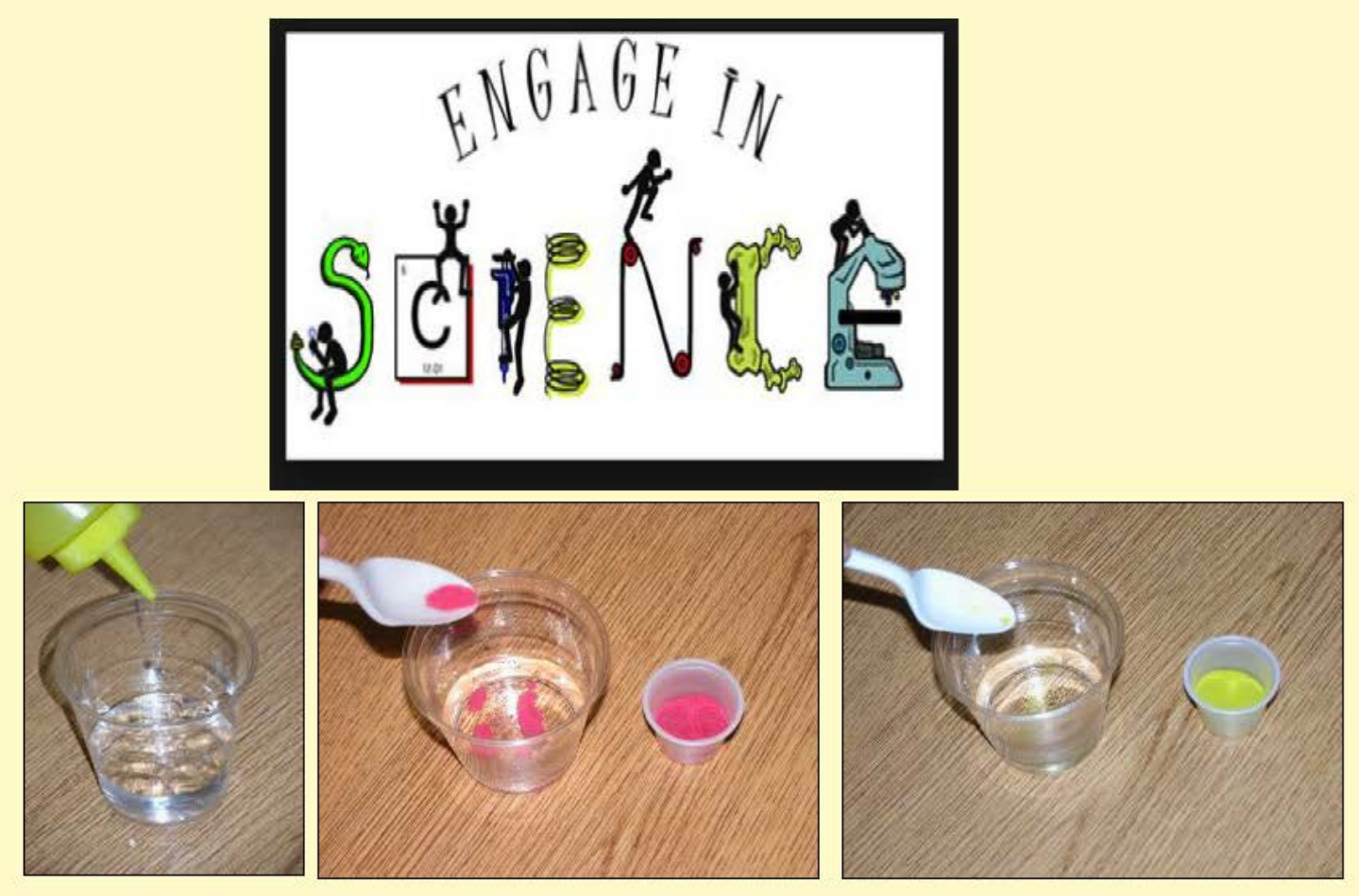




\section{Investigations in Transportation}
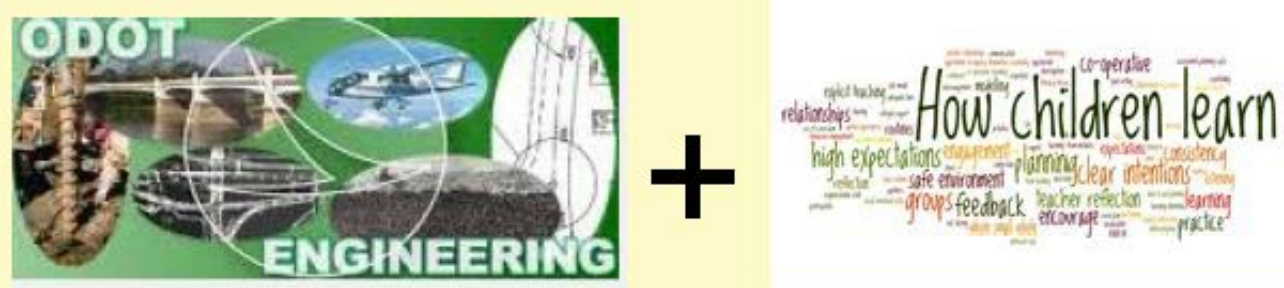

$+$
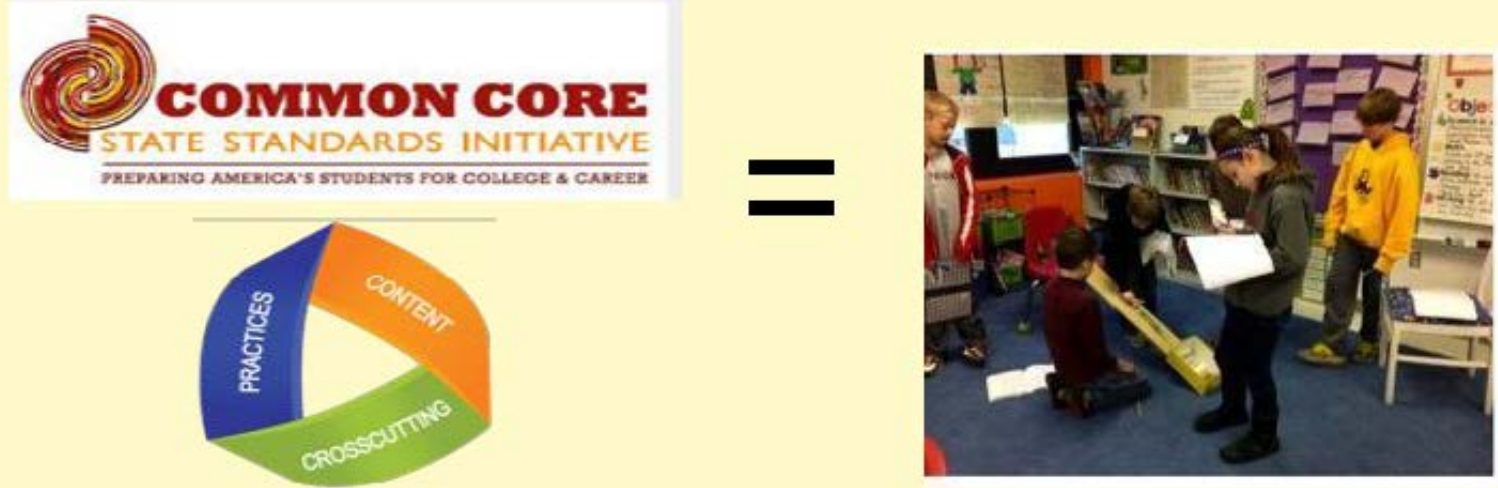


\section{Standards Sense-making}

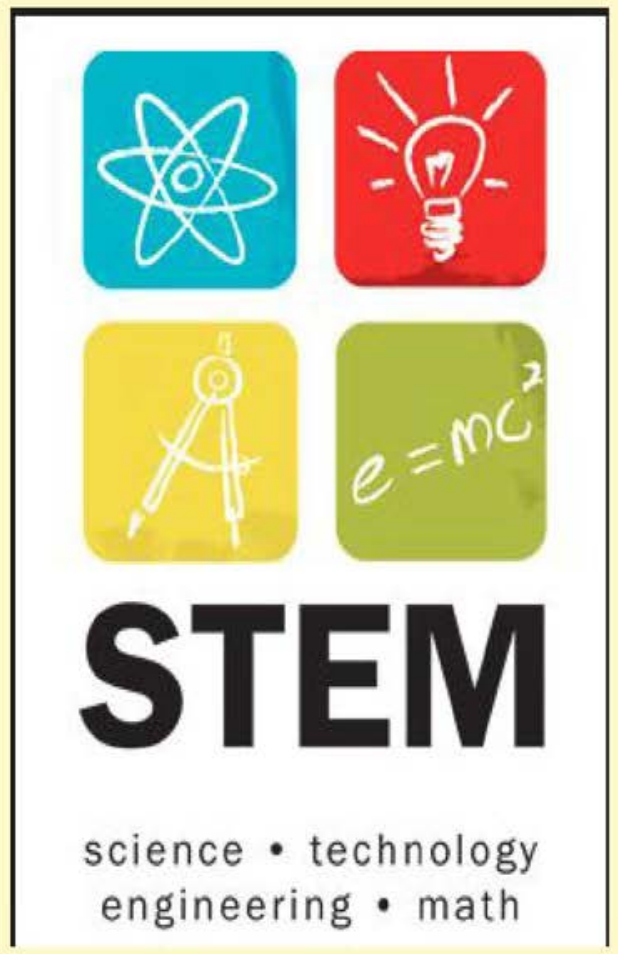

The easiest way to integrate is when a teacher has equal expertise in both math and science and when he or she teaches both subjects.

- Muscovici \& Newton, 2006 


\section{Initial Connections to Real World Work and Dilemmas}

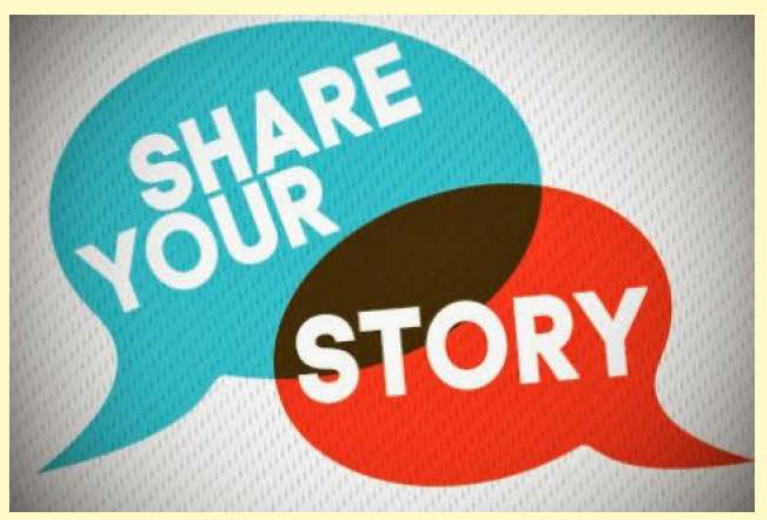

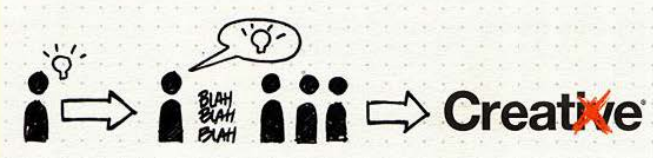




\section{Transportation Connections Grade level relevancy \& CCSS-M}

Table 1. Key topics relevant to science, and the grade at which they are first expected in CCSSM. See CCSSM for exact statements of expectations.

\begin{tabular}{|l|c|}
\hline \multicolumn{1}{|c|}{ Number and Operations } & Grade First Expected \\
\hline Multiplication and division of whole numbers & 3 \\
\hline Concept of a fraction $a / b$ & 3 \\
\hline Beginning fraction arithmetic & 4 \\
\hline The coordinate plane & 5 \\
\hline Ratios, rates (e.g., speed), proportional relationships & 6 \\
\hline Simple percent problems & 6 \\
\hline Rational number system/ signed numbers-concepts & 6 \\
\hline Rational number system/ signed numbers-arithmetic & 7 \\
\hline \multicolumn{1}{|c|}{ Measurement } & Grade First Expected \\
\hline Standard length units (inch, centimeter, etc.) & 2 \\
\hline Area & 3 \\
\hline Convert from a larger unit to a smaller in the same system & 4 \\
\hline Convert units within a given measurement system & 5 \\
\hline Volume & \\
\hline Convert units across measurement systems (e.g., inches to cm) & 5 \\
\hline
\end{tabular}




\section{What Makes an Effective Unit?}

- Identify Desired Results

- Assessment Evidence

- Learning Plan

- Assess and Reflect
- Alignment to Standards

- Conceptual and Instructional Shifts

- Instructional Supports

- Monitoring Student Progress

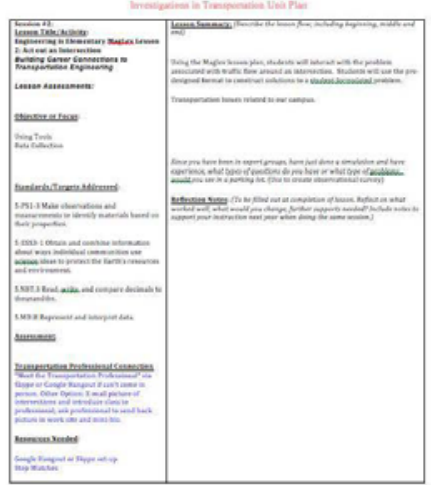




\section{Effective Instructional Model}

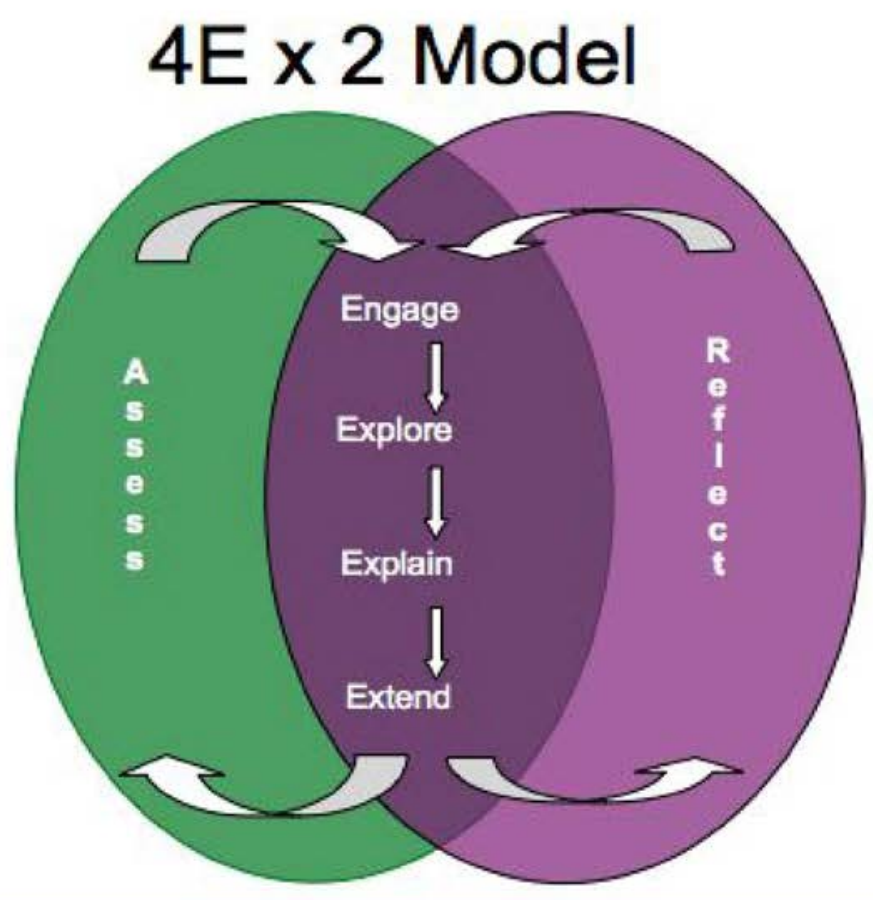




\section{Industry professionals brainstorm possible "dilemmas" to narrow down our group discussions which leads to project selection.}

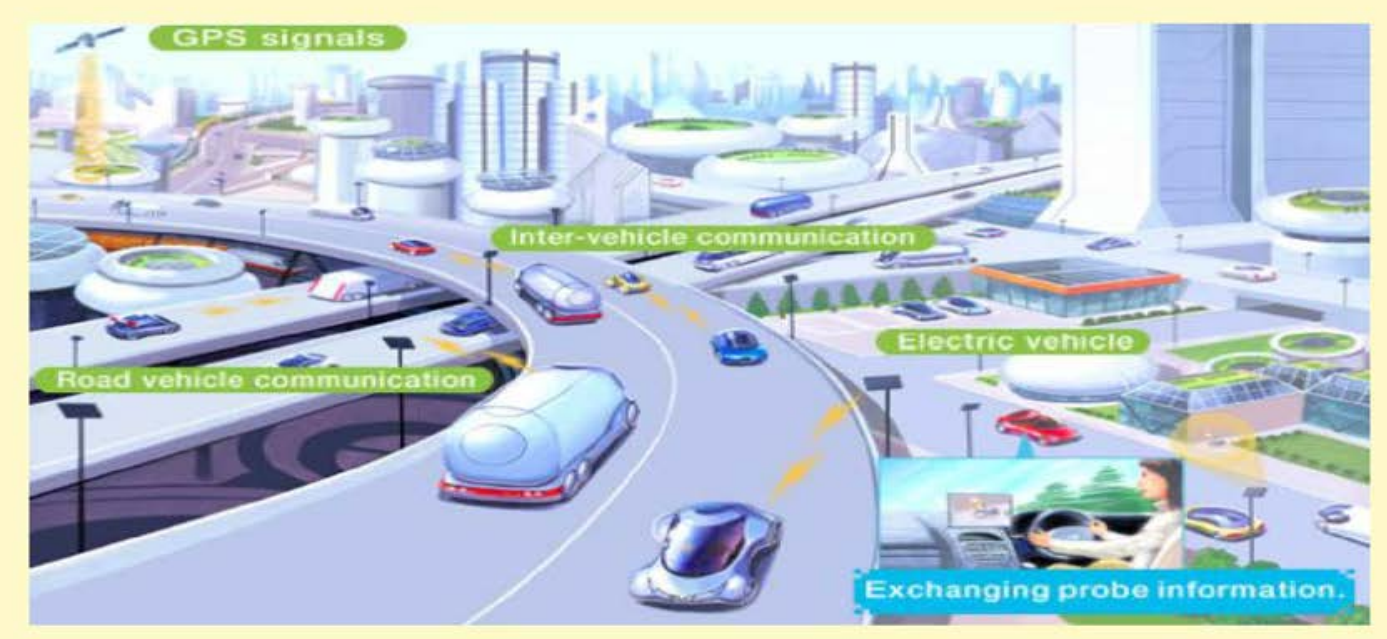

Transportation Unit Ideas and Themes Google Doc 


\section{Creating the Unit Plan}

vicn uy mecn

Week \#1: Introduction: Undorstanding the rolationship betwoen docimals, fractions, and peceseats; data collection; interproting data; secing patterns in data; analyzing data sots of professionals; career pathways-student identity:

Science: Awareness/Community Connection

Math: Create Survey (student) tools; data collection

Language Arts: Picture Book (Career, connection to transportation) Writing Journal, letter home to tell parents about our leacoings

Art: Journal Covers (Make it personal)

Transportation Professionals:

Session \#2: Meet the Professionals
Week \#2: Choosing Appropriato Tools; Inforsoction Count App; Parking Lot Dimensions Google; Turning radius, width of aisle; constraints; for engineering dosign; Task: Car dimension -minimum, maximum, (avorsge) most froquent

dimensions; ombed ressoning; how to blusprint parking fot; impact on watershed (bring in expert from water sorvices); Tualatin Water Services; road density within watershod; larger world context

Science: Awareness of Our School Campus (observe Kindy Pick-up)

What have we learned? What do we Need?

Video survey (professionals)

Math: Discussion of Data from survey (weekend); data (map) represent (formats)

Language Arts: Pressing needs/improve traffic flow; safety; compare to other designs

Art: Journal Covers (Make it personal)

Transportation Professionals:

Session \#7: Support for Initial Data

Session \#8: Data Analysis Discussion

Week \#4: Power Point presentation of project or Psezil

Week \#3: Auto-Cad Info from Professionals; soreadsheot for traffic count and initial analvsis: 


\section{Part 2: Unit Implementation \& Participation}

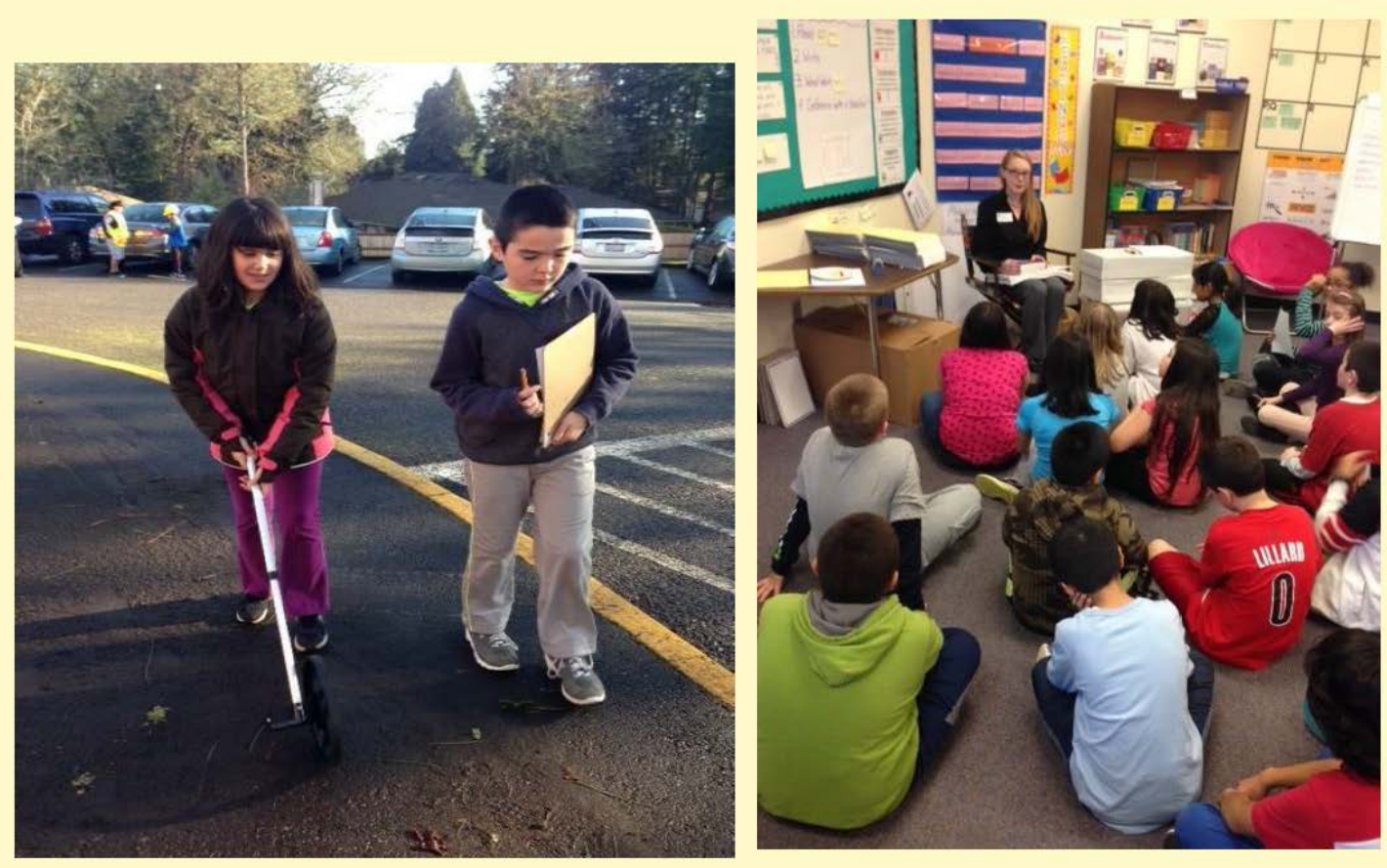




\section{Bringing Colleagues on Board Unit Revision at Chehalem}

\section{Lesson Plan: \\ Session \#1 Example}

Results: Originally, this unit was scheduled to be delivered in the fall. Due to scheduling, curriculum and group constraints, the unit was delivered in January and in a shortened format. The students and staff devoted half a day for 16 days. The result was a compacted delivery model with some reduction in both time and content. The results of these lessons were evaluated and changes were made to improve the lessons for the following years delivery. 


\section{Bringing Colleagues on Board Unit Revision/Plan at Tobias}

\section{Transportation Unit 1.0}

\begin{tabular}{|c|c|c|c|c|}
\hline Monday & Tuesday & Wednesday & Thursday & Friday \\
\hline Jan. 5 & Jan. 6 & Jan. 7 & Jan. 8 & Jan. 9 \\
\hline \multicolumn{5}{|c|}{ Week One Focus: How to Collect and Interpret Data/Career Pathways } \\
\hline & $\begin{array}{l}\text { Session } 1 \text { - } \\
\text { Parking lot walking } \\
\text { field trip. } \\
\sim \text { Record } \\
\text { observations and } \\
\text { issues from } \\
\text { different POV's. } \\
\text { Reflection Essay } \\
\text { titled "Parking Lot } \\
\text { Dilemmas" }\end{array}$ & $\begin{array}{l}\text { Session 2-meet } \\
\text { the professional } \\
\sim \text { EIE MagLev } \\
\text { Lesson }\end{array}$ & $\begin{array}{l}\text { Session 3-Indian } \\
\text { Hills Walking Field } \\
\text { Trip } \\
\sim \text { Record data } \\
\sim \text { Slideshow? }\end{array}$ & $\begin{array}{l}\text { Session 4- } \\
\text { Formulate survey } \\
\text { questions from IH } \\
\text { data. }\end{array}$ \\
\hline $\begin{array}{l}\text { Read:Rosie } \\
\text { Revere } \\
\text { Engineer }\end{array}$ & $\begin{array}{l}\text { Read: This is the } \\
\text { Way We Go to } \\
\underline{\text { School }}\end{array}$ & $\begin{array}{l}\text { Read: } \text { Modes of } \\
\text { Transportation ABC } \\
\text { Book of Rhymes }\end{array}$ & $\begin{array}{l}\text { Read: } \\
\text { Transportation } \\
\text { Inventions Which } \\
\text { came first? }\end{array}$ & $\begin{array}{l}\text { Read: parts of } \\
\text { Tomorrow's } \\
\text { Transpertation pg } \\
18 \text { What Kind of } \\
\text { Person are You? }\end{array}$ \\
\hline
\end{tabular}




\section{Student Materials and Resources}

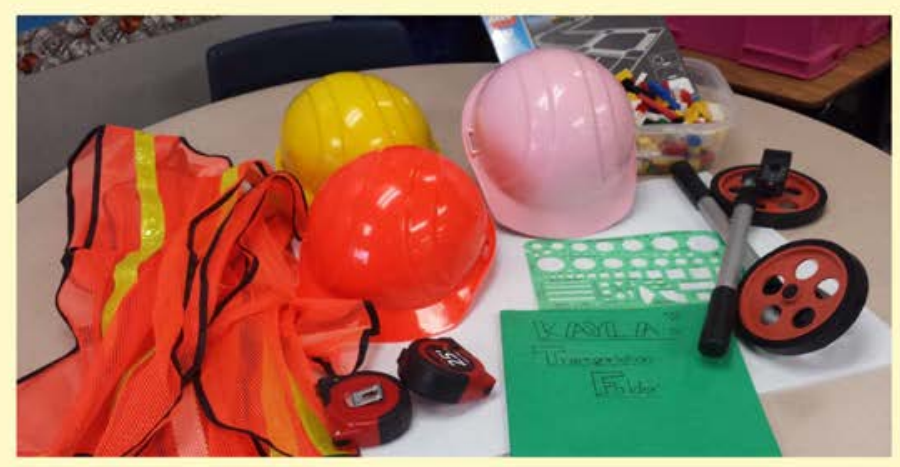

Students were able to use real world tools and relevant text in order to enhance their learnings and connections.

Some journal entries were focused on building background knowledge and connecting with informational text.

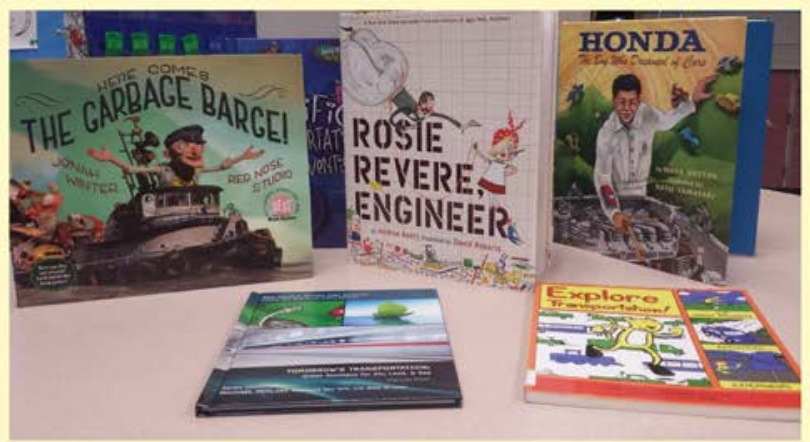




\section{Transportation Professional: Partnerships and Relationships}

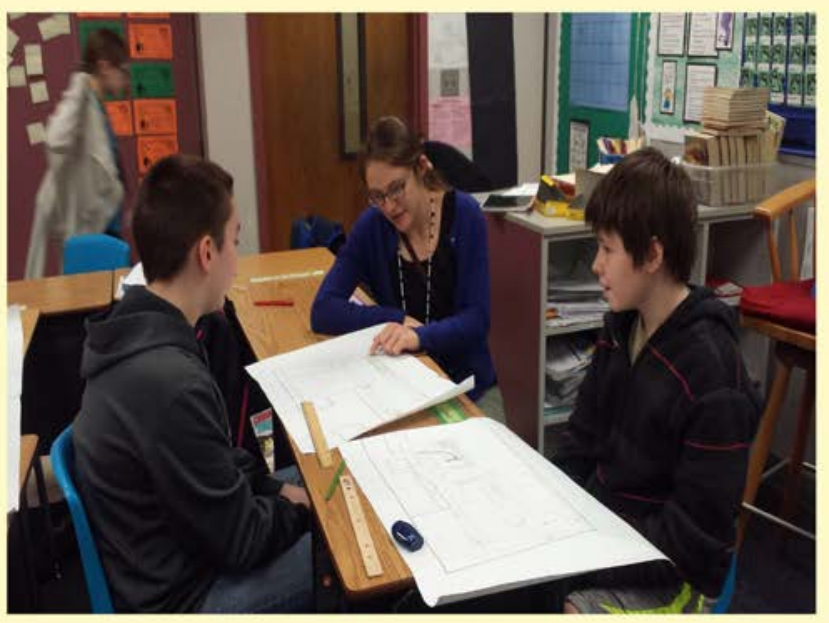

Students met with professionals who brought both expertise and a "sense of authenticity" to student's work.

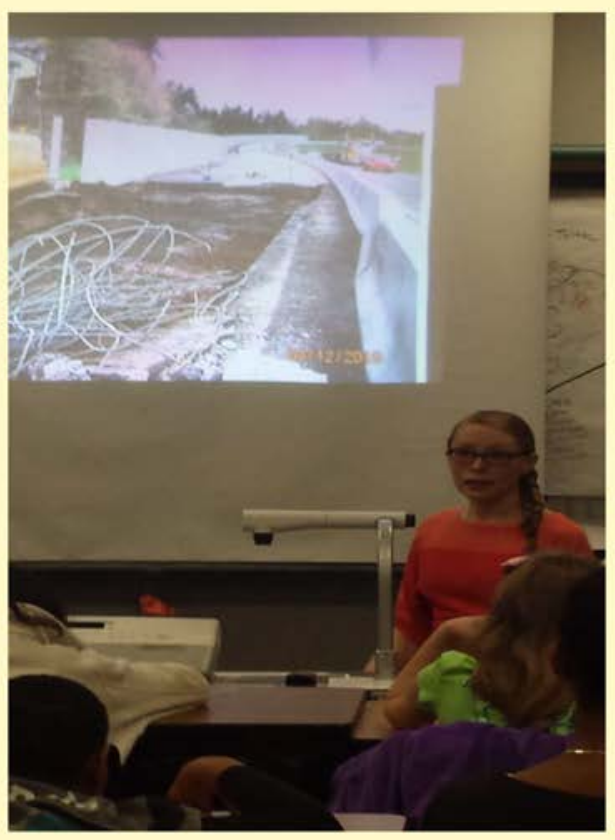




\section{Spending Time with professionals}
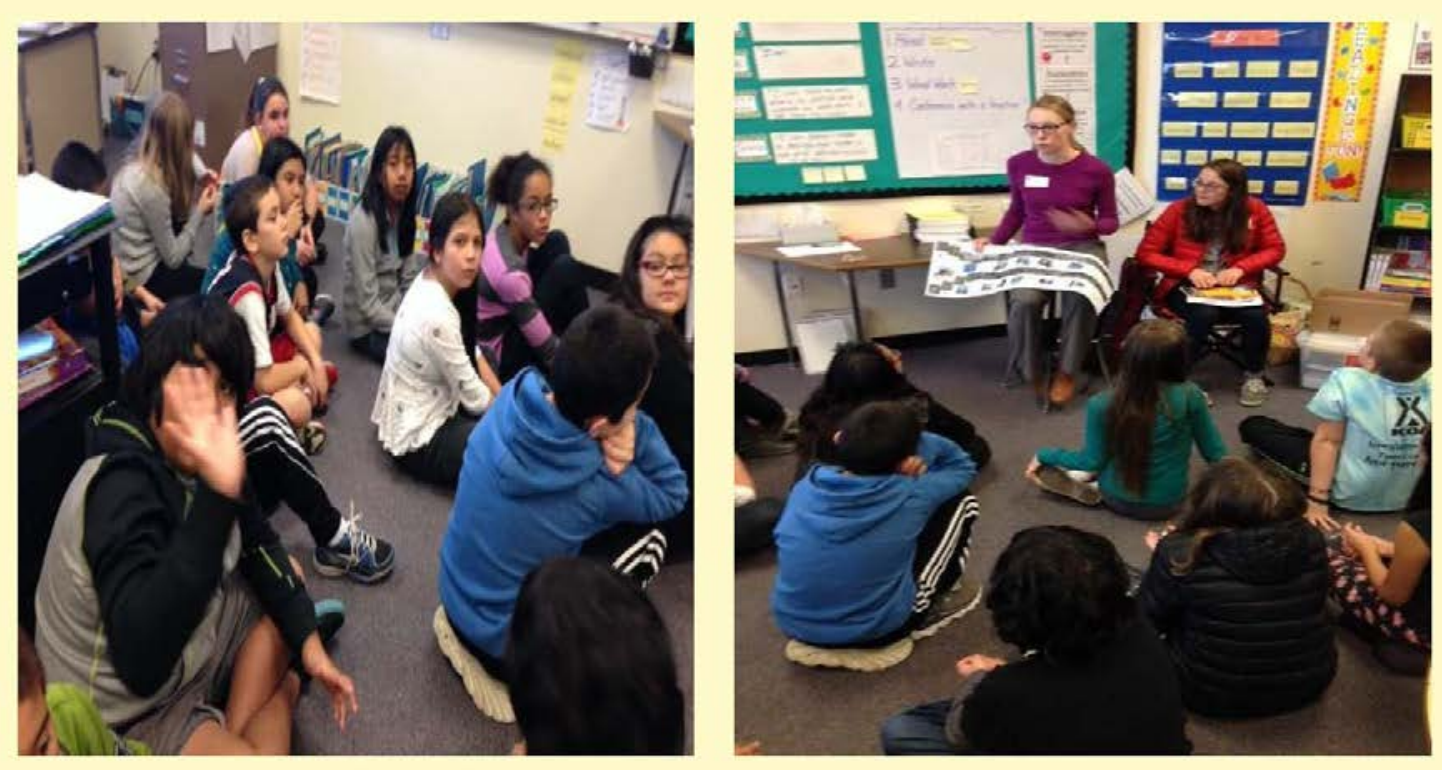

Gathering information and asking questions of a professional was power 


\section{Implementation: Data Collecting Crew}

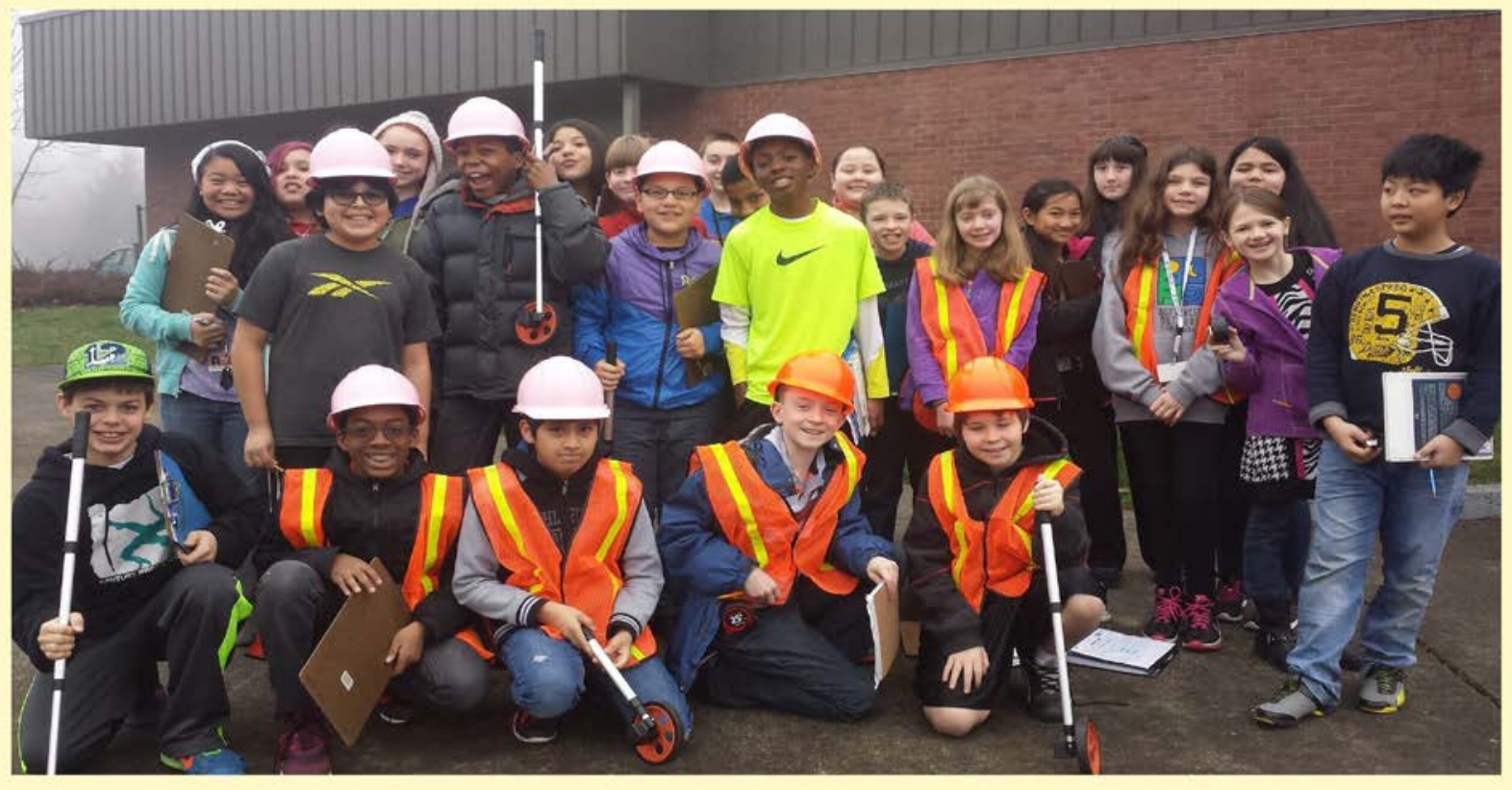

Students preparing to measure, record and report their findings. 


\section{Collecting Further Data}
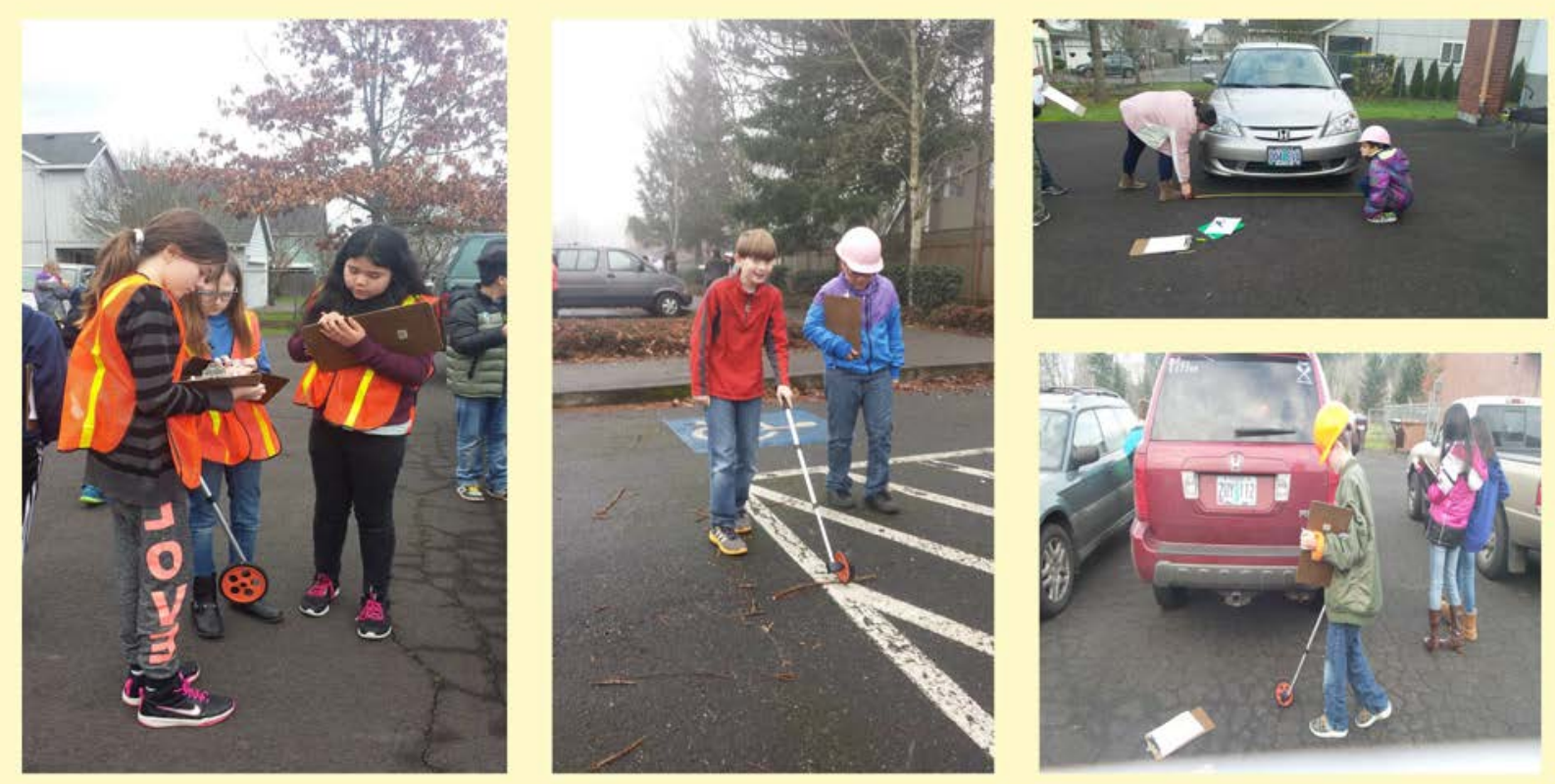

Students interact with the physical environment to aid in the group "dilemma" solution. 


\section{Working on "Dilemma" Solutions}

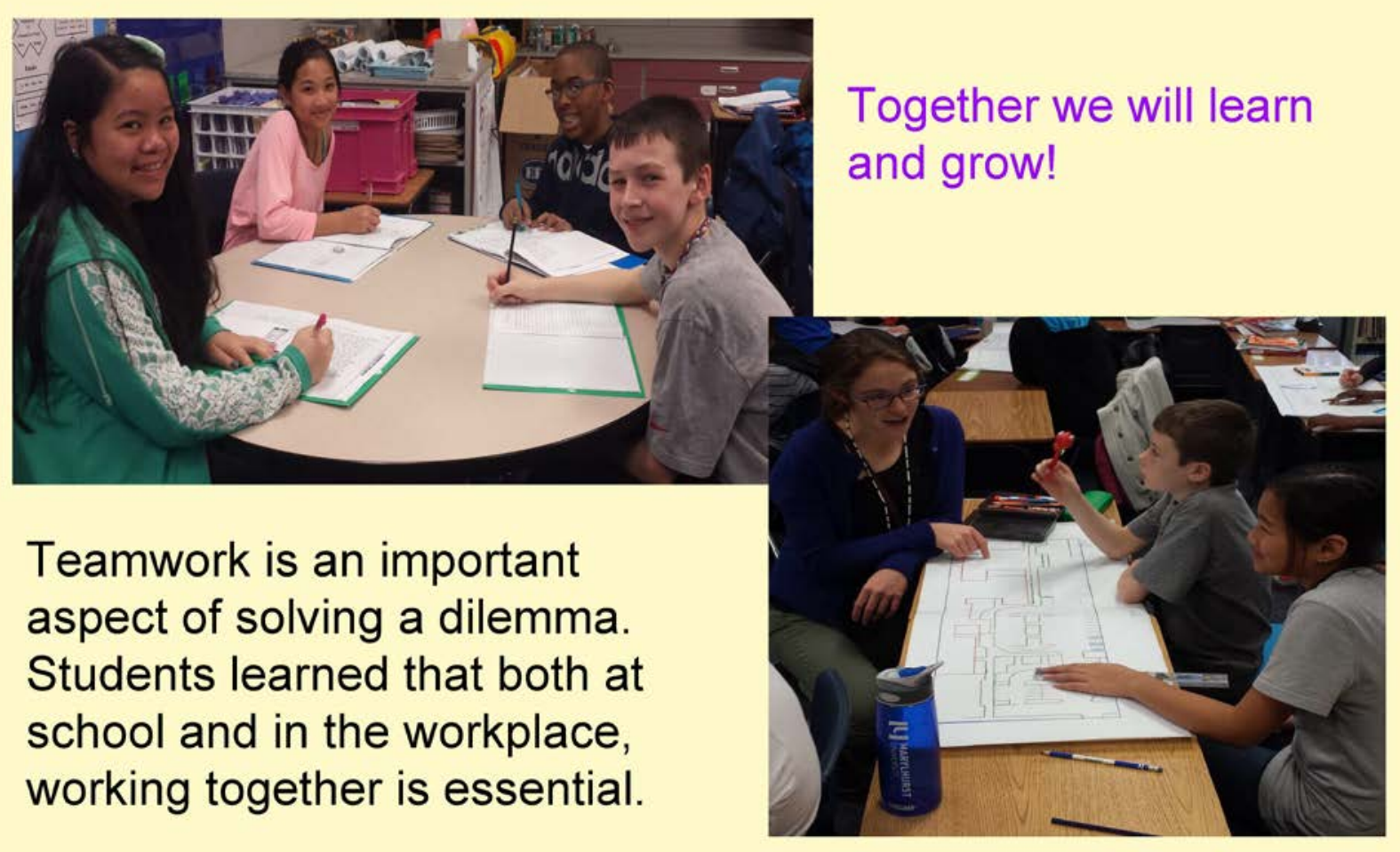


Transportation Research and Education Center

Portland State University

1900 S.W. Fourth Ave., Suite 175

Portland, OR 97201 